Published in final edited form as:

Exp Cell Res. 2009 February 15; 315(4): 583-601. doi:10.1016/j.yexcr.2008.10.043.

\title{
ERBBs in the gastrointestinal tract: Recent progress and new perspectives
}

\author{
William H. Fiske ${ }^{a}$, David Threadgilld ${ }^{d}$ and Robert J. Coffey ${ }^{a, b, c,{ }^{*}}$ \\ aDepartment of Medicine, Vanderbilt University Medical Center, Nashville, TN 37232, USA \\ bDepartment of Cell and Developmental Biology, Vanderbilt University Medical Center, Nashville, \\ TN 37232, USA \\ 'Department of Veterans Affairs Medical Center, Nashville, TN 37232-2279, USA \\ ${ }^{\mathrm{d} D e p a r t m e n t}$ of Genetics and Lineberger Cancer Center, University of North Carolina, Chapel Hill, \\ NC 27599, USA
}

\begin{abstract}
The gastrointestinal epithelium does much more than provide a physical barrier between the intestinal lumen and our internal milieu. It is actively engaged in absorption and secretion of salt and water via ion transporters, exchangers and selective ion channels. It is also a continuously self-renewing epithelium that undergoes ordered growth and differentiation along its vertical axis. From this dual perspective, we will consider the actions of the ERBB family of ligands and receptors in the maintenance of gastrointestinal homeostasis and discuss instances when the actions of this family go awry such as in cancer and Ménétrier's disease.
\end{abstract}

\section{Keywords}

ERBBs; Colorectal cancer; Ménétrier's disease

\section{Introduction}

This review is intended to highlight recent important advances in our understanding of roles for ERBBs in gastrointestinal biology and pathology. We published a similar review in Gastroenterology in 1995 [1], and it is gratifying to note the progress that has been made in this field since that time. More recently, we provided an update on EGF receptor (EGFR) ligands in this journal [2]. Due to space constraints, this review perforce is highly selective, and we apologize in advance to our colleagues for omissions of relevant published work. The focus will be on selected topics where substantial progress has been made, e.g., transactivation of the EGFR, interactions between microbes in the gut and EGFR and insights into gastrointestinal homeostasis based on relevant genetic manipulations in the mouse. We also will point out gaps in our knowledge and emerging areas of opportunity. This review is not intended to be comprehensive. For example, the liver and pancreas are not discussed, although the interested reader is referred to several reviews related to the pancreas $[3,4]$.

(C) 2008 Elsevier Inc. All rights reserved.

* Corresponding author. Suite 4140 MRB III, 465 21st Avenue South, Vanderbilt University, Nashville, TN 37232 , USA. Fax: +1 615 343 1591. robert.coffey@vanderbilt.edu (R.J. Coffey).. 


\section{General background}

The four members of the ERBB family are depicted in Fig. 1. In contrast to the other family members, ErbB3 lacks intrinsic tyrosine kinase activity but contains 6 PI3-K binding sites within its cytoplasmic tail. Family members can homo- and heterodimerize. Preformed dimers may exist [5], but ligand binding results in oligomerization of the receptors, activation of intrinsic tyrosine kinase activity and transphosphorylation of tyrosine residues on the partnered receptor that initiates a complex signal transduction cascade. ErbB2 lacks a ligand but is thought to be the preferred binding partner of the other ErbBs [6,7]. All seven of the vertebrate EGFR ligands are synthesized as type-1 transmembrane proteins (Fig. 1). Upon insertion into the plasma membrane, they undergo ectodomain cleavage by cell surface proteases to release soluble ligand that then engages the receptor. In some cases, membrane-bound ligand is not cleaved, and can signal through adjacent receptor-bearing cells (juxtacrine signaling), a process best documented for HB-EGF [8-10]. Considerably more detail on these topics is presented elsewhere in this monograph.

In the normal adult human gut and in a battery of polarizing human colorectal cancer (CRC) cell lines, EGFR is found predominantly at the basolateral surface [11], as presumably are ErbB2-4 [12]. The pathophysiological significance of apical EGFRs, if any, is less certain [13]. At sites of acute and chronic injury, basolateral EGFRs become exposed to the luminal environment and may be accessed by endogenous luminal EGFR ligands such as EGF or the administration of EGF enemas [14]. Playford and Wright introduced the apt term "luminal surveillance peptide" to describe the action of EGF that is secreted into the gut lumen by the salivary gland and Brunner's glands [15]. A similar phenomenon was described by Welsh et al. for apically released heregulin accessing basolateral ErbB3 and 4 in the damaged lung [16]. All components of the EGFR axis (defined as the proximal events in activation of EGFR) are found at the basolateral compartment of two human polarizing CRC cell lines (HCA-7 and Caco-2) derived from well-differentiated CRCs [17]. That is, TGF $\alpha$ and amphiregulin are delivered selectively to the basolateral surface where they are cleaved by TNF- $\alpha$ converting enzyme (TACE)/a disintegrin and metalloprotease (ADAM)-17 to release mature soluble ligand that then binds basolaterally restricted EGFRs.

TGF $\alpha$ is touted to be the most abundant EGFR ligand in the GI tract [18]. David Lee et al. assessed mRNA expression of all of the EGFR ligands (except epigen) from the stomach to the colon in the mouse [19]. Less is known about the precise localization of the ErbB family and its ligands along the vertical axis of the gut. Our impression is that in the normal colon there is a decreasing gradient of expression for TGF $\alpha$ and EGFR from the luminal surface to the crypt base with a sharper gradient for TGF $\alpha$ than EGFR. However, following fasting and refeeding in the rat, TGF $\alpha$ immunoreactivity extends towards the crypt base in the colon (RJ Coffey, unpublished observation). Bertagnoli et al. have observed a similar gradient of EGFR immunoreactivity from the villous tip to the crypt base in the mouse small intestine [20].

A systematic analysis at the protein level of the ERBB family and its cognate ligands along the horizontal and vertical gradient of the gastrointestinal tract has not been performed. Such an analysis should assess total and phosphorylated ERBBs; ideally, this would delineate phosphorylation status of specific tyrosine residues. This may be particularly relevant in the neoplastic state since we have observed that Ras transformation of RIE-1 cells in vitro results in downregulated, yet tyrosine hyperphosphorylated, EGFR [21]. Such a systematic analysis of receptors and ligands has, thus far, been limited due to technical difficulties. Western blotting requires adequate amounts of tissue, and immunohistochemistry is fraught with issues related to specificity, quantification, preservation of antigenicity and fixation artifacts. Application of advances in mass spectrometry may be a useful direction to pursue in this area, especially in 
the assessment of the phosphorylation state of specific tyrosine residues in the cytoplasmic tails of the different ERBBs.

\section{Transactivation of the EGFR}

Transactivation of the EGFR was defined operationally by Ullrich et al. as G Protein-Coupled Receptor (GPCR)-triggered signaling (specifically MAP kinase and SHC phosphorylation) that was blocked by EGFR tyrosine kinase inhibition. As described below, it initially was thought to be ligand-independent; however, it subsequently was shown to be due to metalloproteinase-regulated cell surface cleavage and release of mature soluble EGFR ligand. Ligand engagement of EGFR activated its intrinsic tyrosine kinase and initiated downstream signaling. Instances of GPCR-triggered, EGFR ligand-independent EGFR activation have been reported, but their mechanistic underpinnings are less clear. Furthermore, one can envision GPCR-mediated EGFR signaling that may not depend upon EGFR tyrosine kinase activation. For example, GPCR activation of Src tyrosine kinase activity may lead to direct phosphorylation of tyrosine (Y) 845 within the EGFR cytoplasmic tail [22]. In this case, EGFR may act as a docking site for SH2-containing proteins and subsequent signal transduction. To further complicate matters, active Src may also activate TACE/ADAM17 and lead to liganddependent EGFR activation [23]. Finally, it should be recalled that there can be GPCRindependent, ligand-dependent transactivation of the EGFR. One example is the phorbol ester TPA, presumably acting as a general cell surface sheddase [24]. However, this action of TPA may be counter-balanced by a PKC-mediated phosphorylation of threonine (T)654 within the cytoplasmic tail of the EGFR that results in receptor internalization and downregulation.

What follows is a brief historical review of GPCR transactivation of the EGFR. In 1996, Ullrich et al. first reported that the GPCR agonists endothelin-1 (ET-1), lysophosphatidic acid (LPA) and thrombin induced tyrosine phosphorylation of EGFR (and ErbB2/c-neu) within 2 min of their administration to Rat-1 fibroblasts [25]. Given the rapid kinetics of this effect, they concluded that EGFR activation must be ligand-independent; however, they were not able to formally exclude this possibility because monoclonal antibodies (mAbs) to block ligand binding to rat EGFR were not available at that time. They postulated that the effect was due to an intracellular release of a negative restraint (likely a phosphatase) on receptor tyrosine kinase activity.

In collaboration with Steve Wiley, we published in early 1999 that a broad spectrum, hydoxymate-based, metalloproteinase inhibitor, batimastat, could reduce the growth of HCA-7 cells and, importantly, that addition of EGF reversed the growth inhibitory effect of batimastat [26]. Similar results were observed in a human mammary epithelial cell line (HMEC); moreover, in, these cells, the metalloproteinase inhibitor reduced the levels of TGF $\alpha$ and AR in the medium, and a combination of batimastat and an EGFR mAb that blocked ligand binding resulted in cooperative growth inhibition of these cells. This work identified a

metalloproteinase-regulated EGFR activity that was mediated by endogenous EGFR ligands.

Later in 1999, Ulrich et al. revisited their initial contention that GPCR transactivation of the EGFR was ligand-independent [27]. Using Rat-1 cells expressing a chimeric human EGFR ectodomain fused to PDGFR transmembrane and cytoplasmic tail, they demonstrated that EGFR transactivation was prevented by a mAb that blocked ligand binding to human EGFR. They implicated HB-EGF as the EGFR ligand mediating this transactivation by exploiting the observation that HB-EGF acts as a receptor for diphtheria toxin. CRM197 (a non-toxic mutant of diphtheria toxin that specifically inhibits the mitogenic effects of cells producing HB-EGF) was able to block EGFR transactivation by GPCR agonists in COS-7 and HEK 293 cells; however, CRM197 did not affect exogenous EGF-induced EGFR tyrosine phosphorylation. Likewise, batimastat was able to abrogate GPCR agonist and TPA transactivation of the EGFR 
in COS-7 cells. Finally, batimastat was shown to prevent bombesin (another GPCR agonist) and TPA-induced tyrosine phosphorylation of EGFR in a prostate cancer cell line, PC3. Consistent with our earlier work [26], batimastat was able to reduce baseline tyrosine phosphorylation of EGFR in these cells.

These studies established that GPCR transactivation of EGFR was rapid and EGFR liganddependent but did not identify the specific metalloproteinase. By noting that TPA-, but not GPCR-induced tyrosine phosphorylation of EGFR, was sensitive to protein kinase C inhibition, they suggested that at least two distinct metalloproteinase-dependent transactivation pathways existed. As noted above, work from our lab has shown that TACE/ADAM-17 localizes to the basolateral surface of polarized HCA-7 cells and that a selective TACE/ADAM-17 inhibitor WAY022 blocks cell surface release of AR and TGF $\alpha$ in these cells [17].

These original observations have spawned a small cottage industry related to GPCR transactivation of EGFR in general [28] and in the gastrointestinal tract in particular (see Table 1). The role of EGFR transactivation in chloride secretion will be discussed in more detail as it illustrates several points we wish to highlight (Fig. 2). Barrett et al. identified one of the first examples of GPCR transactivation of EGFR in the gut. Using a polarizing human colorectal cancer cell line (T84), they showed that the muscarinic (M) agonist carbachol (CCh), a stable analogue of the neurotransmitter acetylcholine, transactivates EGFR in a TGF $\alpha$-dependent manner [29]. By binding to the basolateral M3 receptor (a GPCR), CCh stimulates apical chloride secretion by a mechanism that requires increases in intracellular calcium (left panel in Fig. 2A). The active secretion of chloride ions provides the driving force for intestinal fluid secretion. Binding of $\mathrm{CCh}$ to the $\mathrm{M} 3$ receptor also results in a rapid metalloproteinasedependent release of TGF $\alpha$ into the basolateral medium and avid consumption by basolateral EGFRs (right panel in Fig. 2A), activation of EGFR and transmission of an ERK-mediated signal that blunts apical chloride secretion. The CCh-mediated transactivation of EGFR and subsequent suppression of chloride secretion does not appear to involve PI3-K, unless PTP1B, which dephosphorylates a number of EGFR tyrosine residues, is suppressed [30].

Interestingly, administration of EGF and TGF $\alpha$ to the basolateral compartment also blunted chloride secretion but through ERK and PI3-K signaling and, in the latter instance, this may involve protein tyrosine phosphatases, including PTP1B [30]. The authors suggested that exogenous EGF and TGF $\alpha$ may alter the activity of phosphatases that then dephosphorylate certain key EGFR residues differently than CCh-regulated, TGF $\alpha$-mediated EGFR transactivation. In these experiments, exogenous EGF was more potent than TGF $\alpha$ and elicited EGFR-ErbB2 heterodimerization that was not seen with equivalent concentrations of TGF $\alpha$. This work demonstrates a growth-independent effect of endogenous TGF $\alpha$ and supports our original contention that TGF $\alpha$ acts locally [31]. In contrast, activation of PAR-2 results in increased cAMP and ligand-independent transactivation of EGFR that stimulates CFTRmediated chloride secretion (Fig. 2B) [32]. In normal mouse colon, EGF inhibits cAMPdependent ion transport [33], but, in the background of inflammation, exogenous EGF also stimulates sodium absorption (Fig. 2C) [34]. These studies emphasize the potential of EGFR phosphorylation and dephosphorylation mechanisms to regulate recruitment of alternate downstream signaling pathways following EGFR activation by different stimuli.

Based on these observations, it is tempting to speculate on potential mechanism(s) underlying the diarrhea that is seen in $25 \%$ of patients receiving the EGFR neutralizing mAb cetuximab. One could envision that EGFR blockade impairs the dampening of $\mathrm{CCh}$-induced chloride secretion but also abrogates the sodium absorption that takes place in the setting of ongoing inflammation, a state that is increasingly linked to neoplasia. Obviously, one must also consider the effects of EGFR blockade on growth and repair processes that may also contribute to the 
diarrhea associated with pharmacological blockade of the EGFR, as well as its effects on microbes in the gut (see next section).

A question that arises is how many other signaling pathways act through EGFR. Recent studies by Steve Wiley et al. in human mammary epithelial cells (HMEC) have found that EGFR is a central coordinator of many disparate signaling inputs. In addition to activating GPCRs (LPA receptors, calcium-sensing receptors, purinergic receptors), administration of VEGF, GH, $\mathrm{TNF} \alpha$ and IGF results in EGFR activation [35]. Moreover, ERK phosphorylation in response to general stressors (sorbitol and anisomycin) was dependent on EGFR kinase activity. However, not all roads converge upon EGFR since ERK phosphorylation following HGF activation of Met was not dependent on EGFR signaling. On the other hand, in two colon cancer cell lines (LoVo and Caco-2), Tarnawski et al. reported that $\mathrm{PGE}_{2}$-induced c-Met phosphorylation was dependent upon EGFR activation [36]. These differing results may reflect the contextual nature of signaling responses.

We wish to make several final points. An emerging theme is the convergence of signaling pathways at the level of EGFR, and that the EGFR axis acts as a central hub in integrating many, but certainly not all, cell surface signaling events. One interesting example is the feedforward action of EGFR activation and its upregulation of COX-2. Amphiregulin upregulates $\mathrm{COX}-2$ expression. The COX-2 product, $\mathrm{PGE}_{2}$, induces expression of amphiregulin that binds and activates EGFR that, in turn, further upregulates COX-2 [37]. It is important to note that GPCRs can signal independently of EGFR [38]. GPCR transactivation of EGFR has been documented in vivo [39]; however, it is only $10 \%$ as potent as exogenous EGF in activating EGFR. Deconstructing the contribution of EGFR activation to GPCR signaling will be complicated by identifying whether the effect is ligand-dependent or independent and, if it is ligand-dependent, which ligand and which metalloproteinase cleaves that ligand. Such an analysis may be further complicated by the phenomenon of auto- and cross-induction [40,41], as well as the recent identification of a tyrosine kinase-independent action of EGFR [42]. Finally, one must also consider how GPCR transactivation of EGFR is terminated. Recent studies have identified PKC $\alpha$-mediated feedback inhibition as one such mechanism [43-45].

\section{Gut microbes and EGFR}

Although EGFR and other ErbB receptors are involved in normal gastrointestinal development and homeostasis (discussed below), they are also utilized by various infectious agents in causing human disease. EGFR is employed by bacteria and viruses as a means of facilitating invasion or cell entry, promoting cell survival early in the infectious process and also may play a role in neoplastic progression that is associated with certain infections, such as

Helicobacter $(H$.) pylori. This section will review some of the ways in which microorganisms interact with the ERBB system within the gut.

Enteropathogenic Escherichia coli (EPEC) is a diarrhea-causing pathogen that is responsible for significant morbidity and mortality worldwide. Evidence suggests that EGFR signaling may play a role in E. coli disease pathogenesis [46-48]. Such a link was suggested initially when it was observed that oral administration of EGF to New Zealand white rabbits prevented E. coli colonization of the small and large intestine and prevented diarrhea and weight loss in the rabbits [47]. This observation may also have relevance to cetuximab-associated diarrhea. Rather than being due to altered Cch-mediated chloride secretion, EGFR blockade may facilitate pathogen-induced diarrhea. Additionally, internalization of EPEC into human renal epithelial cells was inhibited by administration of the EGFR tyrosine kinase inhibitor AG1478 [48]. 
In $\mathrm{C} 2_{\mathrm{BBE}}$ intestinal epithelial cells infected with EPEC, there was a progressive increase in phosphorylation of EGFR Y1068. Furthermore, $\mathrm{C} 2 \mathrm{BBE}$ monolayers treated with filtersterilized supernatants of wild-type EPEC also stimulated Y1068 phosphorylation (although it was comparatively less than when EPEC was present), suggesting that a secreted element may be acting to induce this phosphorylation event. EGFR tyrosine phosphorylation was inhibited by administration of AG1478, and this also attenuated EPEC-induced Akt and ERK1/2 phosphorylation. When EGFR was inhibited by AG1478 in the setting of EPEC infection, cell survival was decreased and IL-8 production was inhibited. These findings suggest that EPEC can utilize the EGFR to promote host cell survival and increase IL-8 production [46].Itis possible that apoptosis of host cells early in bacterial infection is detrimental to the pathogen, and that promoting host cell survival is important in disease pathogenesis. Pseudomonas aeruginosa has also been shown to activate EGFR and downstream ERK and PI3-kinase activity in a similar manner [49].

Clostridium difficile (C. diff) acts through a similar pathway. C. diff secretes two major toxins, toxin $\mathrm{A}$ and toxin $\mathrm{B}$, which are both high molecular weight exotoxins and are responsible for the watery diarrhea characteristic of $C$. diff infection. Toxin B induces EGFR-mediated activation of ERK1/2 phosphorylation, leading to release of IL-8 from human colon cell lines, NCM460 and HT-29. Inhibition with AG1478 or EGFR neutralizing mAb blocks EGFR and ERK activation, along with release of IL-8. TGF $\alpha$ was implicated as the ligand responsible for activating EGFR in this system [50].

EGFR appears to be important in the invasion of another bacterial pathogen, Salmonella typhimurium. In vitro exposure of $S$. typhimurium to two human intestinal epithelial cell lines, Henle-407 and T84, induces EGFR tyrosine phosphorylation [33,51]. A strain of $S$.

typhimurium which is non-invasive due to a mutation in the invA gene does not induce this phosphorylation. Addition of EGF to cultured Henle- 407 cells allowed internalization of the invasion-defective strain of S. typhimurium with mutant invA. However, addition of EGF did not cause internalization of adherent, but non-invasive, Eschirichia coli [51]. These data indicate that S. typhimurium can induce EGFR tyrosine phosphorylation which may contribute to its internalization and invasive phenotype. In contrast, McNeil et al. studied S. typhimurium in vitro and in vivo using Egfr (waved-2 [wa2]) mice that have a spontaneous mutation in the EGFR tyrosine kinase domain resulting in markedly reduced (approximately 90\%), but not absent, intrinsic EGFR tyrosine kinase activity. S. typhimurium invaded fibroblasts from $w a 2$ mice as efficiently as fibroblasts from control animals. Moreover, in vivo, $S$.

typhimurium both invaded the gastrointestinal mucosa and penetrated through to the spleen in wa2 mice [52]. Taken together, these data indicate that S. typhimurium has the ability to interact with EGFR and induce phosphorylation, but this does not appear to be a necessary step in invasion. Alternatively, the modest residual EGFR tyrosine kinase activity in wa2 mice may be sufficient to mediate this effect.

Similarly, there is conflicting data on the importance of EGFR on the entry of human cytomegalovirus (CMV) into epithelial cells. In 2003, Wang et al. proposed that EGFR was a receptor responsible for cell entry of the virus [53]. CMV can activate both MAP-kinase [54, 55] and PI3-kinase [56], but a receptor for cell entry and signaling was not identified at the time. Wang confirmed that CMV interacted with EGFR and activated downstream targets of EGFR signaling such as PI3-kinase and Akt. This effect was inhibited by administration of AG1478. Transfecting EGFR-negative MDA-MB453 cells with EGFR cDNA rendered nonsusceptible cells susceptible to CMV cell entry. CMV interacted with EGFR through glycoprotein B, its principal surface envelope protein, and glycoproteinB promoted the heterooligomerization of EGFR with ErbB3 [53]. On the other hand, Isaacson et al. found no correlation between EGFR expression and CMV cell entry in a variety of cell lines (NHDF and HEL fibroblasts, ARPE-19 retinal epithelial cells, UtMVEC and HUVEC endothelial cells) 
nor did EGFR neutralizing mAb block CMV entry into these cell lines [57]. Again, this may indicate that CMV has the capacity in some cases to utilize the EGFR for cell entry and signaling, but that is not necessarily an obligatory step.

In contrast to the above pathogens which cause acute illness, $H$. pylori is an organism that colonizes the stomach during childhood and can lead to lifelong infection in the host if untreated [58]. Approximately half of the world's population is infected with $H$. pylori, and it is known to be associated with diseases such as atrophic gastritis, peptic ulcer disease [59-61], lymphoma of mucosa-associated lymphoid tissue (MALT) and gastric adenocarcinoma [62, 63]. Among the responses of gastric epithelial cells to infection with $H$. pylori is increased expression of EGFR [64], increased expression of EGFR ligands amphiregulin and HB-EGF $[65,66]$ and activation of EGFR signaling [67] which leads to upregulation of COX-2 and VEGF in gastric epithelial cells [68].

Busiello et al. studied the virulence factors associated with changes in EGF-related peptides and EGFR in two human gastric cancer cell lines, MKN28 and AGS [69]. They found that the soluble protein gamma-glutamyltranspeptidase (GGT), a virulence and colonizing factor for H. pylori, retained the ability to upregulate HB-EGF mRNA and protein expression after fractionation from medium of cultured H. pylori strains. Acivicin, a selective GGT inhibitor, counteracted the upregulation of HB-EGF by H. pylori, and upregulation of HB-EGF was not observed following infection of gastric epithelial cells with an isogenic mutant GGT-deficient strain of H. pylori. This effect appeared to be mediated through PI3-kinase and p38 kinase, as their blockade with LY294002 or SB203580, respectively, inhibited H. pylori-induced upregulation of HB-EGF, whereas blockade of MAP kinase with PD98059 had no such effect [69].

In contrast to the above observations showing increased EGFR activity related to $H$. pylori infection, Schiemann et al. observed that infection with $\mathrm{H}$. pylori was associated with reduced mRNA expression of TGF $\alpha$, amphiregulin and HB-EGF [70]. Chronic gastritis due to $H$. pylori was associated with decreased antral EGFR binding compared to healthy controls, as assessed by $\left[{ }^{125} \mathrm{I}\right]-\mathrm{EGF}$ binding. Moreover, in 19 patients with chronic $H$. pylori infection, levels of these ligands increased after eradication therapy. The authors hypothesized that reduced EGFR-mediated gastroprotection may contribute to the pathogenicity of $\mathrm{H}$. pylori infection [70].

These findings highlight the controversy surrounding the impact of $H$. pylori on EGF-related peptide expression in human gastric mucosa. Other groups have found that HB-EGF and amphiregulin are upregulated in the gastric mucosa of individuals infected with $\mathrm{H}$. pylori [71,72], and that this overexpression correlates with an increase in the mitotic index of the gastric mucosa, as assessed by PCNA immunostaining [72]. However, Persico et al. noted decreased expression of TGF $\alpha$ in the gastroduodenal mucosa of individuals infected with $H$. pylori, similar to the observation of Schiemann et al. [73]. In light of these findings, it is clear that more research is needed to further elucidate the interaction between H. pylori, EGF-related peptides and EGFR signaling.

The cytotoxin-associated gene A product ( $\mathrm{CagA})$ is another $H$. pylori virulence factor that is associated with higher grades of gastric inflammation and an increased risk of gastric cancer [74]. Increased expression of EGFR is induced by $H$. pylori infection at both the mRNA and protein level. This effect is limited to CagA+ strains of $H$. pylori and those with an intact type IV secretion system [64]. Upregulation of HB-EGF is also more strongly induced by $\mathrm{CagA+}$ strains of $H$. pylori than by $\mathrm{CagA-}$ strains [67]. It is unknown whether these findings contribute to the increased oncogenic potential of CagA+ strains of $\mathrm{H}$. pylori. 
Finally, it is useful to recall that HB-EGF serves as the receptor for the B fragment of Diphtheria toxin [75].

\section{Homeostasis}

In this section, we will review the gastrointestinal consequences of genetic engineering of the ERBB family and its ligands in the gut. The cumulative evidence suggests that EGFR signaling contributes to mucosal integrity in response to damage and other provocative maneuvers. Targeted disruption of the Egfr in mice results in strain-dependent effects. Using different inbred strains, Threadgill et al. observed implantation lethality in CF-1 mice, midgestation lethality in $129 / \mathrm{Sv}$ mice and perinatal lethality in CD-1 mice with these mice living past weaning, at which time the overall gut architecture appeared normal [76]. However, Miettinen et al. found that Egfr null mice on a mixed background exhibited features of necrotizing enterocolitis (NEC) [77]. Moreover, a body of literature supports that EGFR ligands may prevent NEC [78]. However, these ameliorative effects of EGFR ligands do not prove that loss of Egfr in mouse gut directly causes NEC. It may be that that the NEC phenotype was secondary to multi-organ failure and the overall debilitated state of these mice, or, alternatively, to impaired barrier function and repair capability leading to enteropathogen susceptibility as described above. Experiments comparing Egfr mutant mice in conditions with known bacterial compositions will be required to elucidate whether NEC is a direct or indirect consequence of Egfr deficiency. Nonetheless, more recent genetic data using conditional ablation of Egfr in the gut epithelium using an Egfr conditional allele with the Villin-Cre transgene suggests that NEC and other homeostatic defects are secondary to loss of Egfr which creates a sensitized background [79].

Hypomorphic, homozygous wa2 mice have increased susceptibility to DSS-induced colitis [80], as do TGF $\alpha$ null and epiregulin null mice [81,82]. Conversely, TGF $\alpha$ transgenic mice exhibit decreased injury in response to DSS [83]. The lack of susceptibility to DSS-induced colitis in the EGF, TGF $\alpha$ and AR triple null mice is likely due to differences in strain backgrounds or health status of the respective colonies [19]. These triple null mice, however, do exhibit spontaneous erosions in the duodenum.

Wa2 mice have reduced intestinal adaptation following 50\% small bowel resection $[84,85]$.

Mice overexpressing an assembled mouse EGF cDNA downstream of a rat intestinal fatty acid binding promoter have 2-fold increased levels of EGF protein in the gut and exhibit enhanced intestinal adaptation following small bowel resection [86]. Intestinal adaptation is not affected in TGF $\alpha$ null mice [87], a finding that likely reflects ligand redundancy under these experimental conditions.

The function of ErbB2 and ErbB4 in gastrointestinal homeostasis has not been evaluated because embryos deficient for either die prenatally due to developmental defects of the heart $[88,89]$. However, a conditional allele for ErbB3, which also leads to prenatal lethality when deficient, has allowed its role to be evaluated. Mice lacking ErbB3 in the intestinal epithelium, created by combining an ErbB3 conditional allele with the Villin-Cre transgene, develop normally but show a high frequency of bifurcated villi [90]. The developmental cause of this morphological change is not known but the mutant mice appear to have normal absorption based upon body weight. Mice deficient for ErbB3 in the intestinal epithelium show elevated susceptibility to DSS-induced colitis.

\section{Esophagus}

Increased EGFR signaling appears to play a role in the pathogenesis of both squamous cell carcinoma (SCC) and adenocarcinoma of the esophagus. Increased EGFR expression is common in SCC of the esophagus and has been associated with poor outcomes [91,92].A 
retrospective review of 107 cases of squamous cell carcinoma of the esophagus demonstrated that $68.2 \%$ of cancers had overexpression of EGFR by immunohistochemistry [91]. Increased expression was associated with a higher incidence of vascular invasion, higher local recurrence rates and lower overall survival. Increased EGFR expression has also been associated with higher rates of local spread to regional lymph nodes [92]. Although the majority of SCCs show overexpression of EGFR by immunohistochemistry, only $21 \%$ of primary tumors exhibit DNA amplification of EGFR by Southern blot analysis [93].

Rustgi et al. evaluated the effects of EGFR overexpression by retroviral transduction in normal human epithelial cell lines EPC1 and EPC2. Compared with normal and GFP-transduced primary human epithelial esophageal cells, cell cultures overexpressing EGFR demonstrated a thicker epithelium and basal cell hyperplasia, as well as increased cell migration. These effects were markedly diminished by addition of the EGFR tyrosine kinase inhibitor AG1478 to the medium of these organotypic cultures. The effect of EGFR on cell migration appeared to be dependent upon EGFR-induced upregulation of matrix metalloproteinase-1 (MMP-1) [94], an effect which was mediated by the JAK-STAT pathway [95]. In vivo, a transgenic mouse model of EGFR overexpression in the oral and esophageal squamous epithelia was also studied. Compared with age-matched littermates, transgenic mice overexpressing EGFR in the esophageal mucosa demonstrated increased proliferation in the basal and suprabasal cells, consistent with the findings noted in cell culture [94].

More recently, the same group has used human epithelial cells as a platform to recapitulate esophageal squamous cell cancer. This was accomplished by retroviral-mediated transduction of EGFR, the catalytic subunit of human telomerase ( $h T E R T)$ and $p 53^{R 175 H}$ into normal human esophageal epithelial cells. These transduced cells demonstrated increased migration and invasion, and, in an organotypic 3-dimensional culture system, they formed a high grade dysplastic epithelium with malignant cells invading the stromal extracellular matrix. The invasive phenotype was mediated, in part, by matrix metalloproteinase-9 (MMP-9), and invasion was attenuated by knockdown of both AKT1 and AKT2 [96].

EGFR also appears to play a role in Barrett's-associated adenocarcinoma of the esophagus. Wang et al. showed that EGFR was expressed in 32\% of adenocarcinomas of the esophagus, and that expression of EGFR was associated with higher $\mathrm{T}$ stage, the presence of lymph node metastases and also with a trend toward shorter disease-free survival in multivariate analysis [97]. In addition to increased EGFR immunoreactivity, mutations in EGFR have been detected in $11.7 \%$ of esophageal adenocarcinomas and $14.2 \%$ of cases of Barrett's esophagus [98]. In this study, mutations consisted of the missense L858R mutation and in-frame deletion delE746-A750. Both of these mutations are located in the tyrosine kinase domain of the receptor and previously have been characterized as activating EGFR mutations in non-small cell lung cancer which predict responsiveness to EGFR tyrosine kinase inhibitors [99-102]. The fact that these mutations are present in Barrett's esophagus, as well as adenocarcinoma, suggests that there is a subset of adenocarcinomas of the esophagus in which mutation of EGFR may play an early role in tumorigenesis [98]. TGF $\alpha$ and EGF appear to be involved in mucosal defense in chronic reflux esophagitis $[103,104]$, which is known to be associated with development of esophageal adenocarcinoma [105]. This provides a plausible mechanism through which chronic reflux could promote the neoplastic process in part by stimulating EGFR signaling.

The role of ErbB2, ErbB3 and ErbB4 are less well defined in the pathogenesis of esophageal carcinoma. The ErbB2 gene is amplified in approximately $21-32 \%$ of esophageal adenocarcinomas arising out of Barrett's esophagus and 5-27\% of Barrett's specimens with high grade dysplasia $[106,107]$. Overexpression of ErbB2 by FISH was observed in 19\% of esophageal adenocarcinomas and correlated with poor prognosis [108]. No Barrett's samples 
with low grade dysplasia or intestinal metaplasia without dysplasia demonstrated increased copy number of ErbB2 by quantitative RT-PCR [107]. This indicates that overexpression of ErbB2 is involved in a subset of esophageal adenocarcinomas, although it is a relatively late step in the metaplasia-dysplasia-carcinoma sequence. One uncontrolled Phase I/II study evaluated the use of trastuzumab, a humanized monoclonal antibody that acts on the ErbB2 receptor, in patients with locally advanced esophageal adenocarcinomas that overexpressed ErbB2 by immunohistochemistry. Nineteen patients were enrolled, and median survival was 24 months with a 2-year survival of 50\% [109], numbers that are comparable with historical controls. Due to the small proportion of adenocarcinomas that overexpress ErbB2, accrual for this study was slow, and it was felt that an adequately powered Phase III study would be difficult to perform.

ErbB3 has also been shown to be upregulated in esophageal adenocarcinoma through a proteomic approach using high-resolution, two-dimensional gel electrophoresis and matrixassisted laser desorption/ionization, time-of-flight and tandem mass spectrometry analysis (MALDI TOF MS) [110]. This finding was then validated using qRT-PCR and immunohistochemical analysis on a tissue array. Fifty-one percent of tumors had increased ErbB3 mRNA expression, and 42\% had increased immunohistochemical staining for ErbB3 [110]. mRNA expression for ErbB4 and heregulin has been detected in esophageal mucosa [111], but there is no clear evidence that alterations in their expression play a role in esophageal carcinogenesis.

\section{Stomach}

In the stomach, enhanced EGFR signaling has been implicated in the pathogenesis of Ménétrier's disease (hypoproteinemic hypertrophic gastropathy). In adults, this is a rare, acquired, progressive overgrowth state of the stomach characterized by enlarged gastric folds in the body and fundus of the stomach, hypochlorhydria and protein loss across the gastric mucosa. Characteristic histological findings include foveolar hyperplasia with an expansion of surface mucous cells at the expense of acid-producing parietal cells and pepsinogenproducing chief cells [112]. The condition appears to be associated with an increased risk of malignancy, although the magnitude of this risk is not known [113-118].

Evidence from mice and humans supports a role for excess EGFR signaling in the pathogenesis of Ménétrier's disease [119,120]. TGF $\alpha$ suppresses gastric acidity, stimulates gastric epithelial cell proliferation and induces gastric mucus production, all of which are characteristic features of Ménétrier's disease. Transgenic mice that overexpress TGF $\alpha$ exhibit many features of Ménétrier's disease including enlarged gastric folds, foveolar hyperplasia and reduced numbers of chief cells and parietal cells with hypochlorhydria [121]. Patients diagnosed with Ménétrier's disease exhibit increased immunoreactivity for TGF $\alpha$ [122]. To date, a systematic analysis of other EGFR ligands has not been performed in this disease nor has there been a report of targeted overexpression of any of the other EGFR ligands in the mouse stomach.

Perhaps the strongest evidence for the role of EGFR signaling in the pathogenesis of Ménétrier's disease comes from pharmacologic blockade of EGFR in the treatment of patients with this disease. We now have experience in treating eight patients with Ménétrier's disease with cetuximab, a monoclonal antibody that inhibits the activity of the EGFR. All of the patients treated thus far as part of an FDA-approved clinical trial with four weekly doses of cetuximab have demonstrated clinical improvement in their predominant symptom. They also have exhibited biochemical evidence of significant improvement in a number of parameters that include decreased gastric wall thickness by CT scan, reduced proliferation in the involved stomach (as determined by reduced active phosphorylated MAP kinase) and increased parietal cell mass with decreased gastric $\mathrm{pH}$ (WH Fiske and RJ Coffey, unpublished observation). As 
assessed by electron microscopy, the integrity of tight junctions in the gastric mucosa of a patient with Ménétrier's disease was improved after treatment with cetuximab [123].

In adolescents, there is an abrupt onset, spontaneously reversible form of Ménétrier's disease that has been linked epidemiologically to CMV infection (see Gut Microbes and EGFR section). We recently encountered a patient with acute onset, clinically and histologically documented Ménétrier's disease whose signs and symptoms resolved in the two-month interval from diagnosis to evaluation for entry into the cetuximab trial. We identified CMV nuclear inclusions in his gastric epithelial cells and acute and convalescent serum titers for CMV confirmed the diagnosis (WH Fiske and RJ Coffey, unpublished observation). Thus, CMVinduced Ménétrier's disease can occur in immuno-competent adults. We now exclude patients from our Ménétrier's disease trial if they have evidence of active H. pylori or CMV infection.

ErbB family members also play a role in gastric carcinogenesis. Some of these effects are mediated through infection with $H$. pylori and are discussed in the section on Gut microbes and EGFR. However, there is also evidence that ErbB family members play a more direct role in gastric carcinogenesis as well.

Immunoreactive EGF is present in approximately $26 \%$ of gastric cancers, and the presence of EGF in gastric cancer is associated with a greater degree of gastric wall invasion and lymph node metastasis; the 5-year survival is worse for patients with EGF-positive tumors [124]. EGFR has also been identified in a small subset of gastric cancers, although this is uncommon. In one study, high levels of EGFR immunoreactivity (2+ or 3+ by immunohistochemical staining) were present in 9 of 413 tumor samples (2.2\%), and low level expression (1+ staining) was present in $8.2 \%$ of samples tested [125]. In tumors that demonstrated high levels of expression by immunohistochemistry, FISH almost always demonstrated evidence of gene amplification as the mechanism for overexpression [125]. Inhibition of EGFR signaling does appear to be effective in reducing the growth of human gastric cancer cells both in vitro and in vivo [126]. However, data evaluating the clinical efficacy of pharmacological blockade of EGFR are lacking. There has been one uncontrolled Phase II clinical trial evaluating cetuximab in combination with FOLFIRI as a first-line treatment of advanced gastric or gastroesophageal junction (GEJ) adenocarcinoma [127]. This regimen appeared to be active in gastric cancer with an acceptable rate of toxicity. Further randomized clinical trials evaluating cetuximab in gastric cancer will need to be completed in order to assess its effectiveness.

ErbB2 has been shown to be overexpressed in human gastric carcinomas approximately 8$14 \%$ of the time [128-130] and is associated with a worse prognosis [130-133]. Overexpression of ErbB2 by immunohistochemistry is associated with greater depth of invasion, intestinaltype carcinoma (not diffuse or mixed/anaplastic growth pattern), the presence of liver metastases and more advanced stage $[128,133]$. Trastuzumab, a monoclonal antibody against ErbB2, has been studied in both in vitro and in vivo models of gastric cancer. Trastuzumab inhibited the growth of ErbB2-overexpressing SNU-216 cells. Phosphorylation of ErbB2 and its downstream targets STAT3, AKT and ERK were also inhibited. This effect was synergistic with cisplatin, and an additive effect was seen with trastuzumab plus 5-FU or trastuzumab plus oxaliplatin [134]. In nude mouse xenografts, trastuzumab significantly suppressed the growth of NCI-N87 cells [135]. The combination of trastuzumab with other chemotherapeutic agents appears to be more effective than anti-cancer agents alone in xenograft models [136]. There are anecdotal reports of the efficacy of trastuzumab in individuals with gastric carcinoma [137,138], although large scale clinical trials are lacking.

ErbB3 may play a role in the progression to more dedifferentiated gastric cancers. NUGC-4 cells, derived from a signet ring carcinoma of the stomach, have a constitutively phosphorylated ErbB3 that binds to phosphatidylinositol 3-kinase (PI3-kinase), although similarly derived 
HSC60 cells do not demonstrate phosphorylated ErbB3 or an association of ErbB3 with PI3kinase [139]. In contrast, phosphorylated ErbB3 is not detected in more differentiated cancer cell lines such as SCH, MKN28, MKN74 and HSC57, although total ErbB3 can be detected.

ErbB4 may play a role in gastric carcinogenesis, although its role is not clear. In one study, ErbB4 was not found to be expressed at the mRNA level in normal gastric mucosa. However, it was expressed in 4 of 6 gastric cancers evaluated [111]. This same study performed immunohistochemical analysis as well. In the normal stomach, immunostaining for ErbB4 was detected in surface epithelial cells but not gastric fundic or pyloric glandular cells. ErbB4 staining was identified in all gastric cancers evaluated and appeared to be most intense in signet ring cancers [111]. Mutations of ErbB4 in gastric cancer are rare. In a panel of 180 human gastric cancers, mutations were found in only $1.7 \%$ of cases [140].

\section{Intestine and colorectum}

We have employed a genetic approach to identify a role for EGFR signaling in a post-initiation, early stage of intestinal neoplasia. Apc Min (multiple intestinal neoplasia) mice are heterozygous for an ENU-induced mutation in the Apc gene and develop multiple polyps in the small intestine, and occasionally colon, at 3 months of age. Egfr null mice exhibit embryonic and/or perinatal lethality on most genetic backgrounds, but $w a 2$ mice harbor a spontaneous mutation in the tyrosine kinase domain that produces a hypomorphic allele of Egfr. As mentioned above, wa2 mice exhibit a 90\% reduction in EGFR tyrosine kinase activity but are viable and fertile. We crossed $w a 2$ mutant mice to $A p c^{M i n}$ mice and evaluated tumor multiplicity at 1 and 3 months of age [141]. We were able to demonstrate that EGFR does not have a role in tumor initiation (at 1 month there were just as many initiated events as determined by the number of microadenomas and crypts containing cells with nuclear $\beta$-catenin). There was, however, a $90 \%$ reduction in the number of macroadenomas at 3 months of age. Thus, EGFR signaling plays a critical role in the advancement from micro to macroadenomas in what we refer to as the establishment phase of intestinal tumorigenesis. The few polyps that do form on a wa2 background are equivalently-sized to $A p c^{M i n}$ polyps arising in Egfr wild-type mice and expand in an EGFR-independent manner over a 9 month follow-up as determined by size and by histology in a small cohort of mice by linear regression analysis. Fichera et al. also have observed that EGFR signaling is required for early colonic tumor formation in mice treated with the carcinogen azoxymethane [142]. The precise mechanism by which EGFR signaling contributes to tumor establishment is not known but is believed to be through reduced proliferation based upon results of Fichera et al. Treatment of established human colonic tumors in nude mouse xenografts (HCA-7 and HCT-116) with a small molecule irreversible inhibitor of EGFR signaling, EKB-569, resulted in concentration-dependent tumor growth inhibition, revealing a role for EGFR signaling during later stages of tumorigenesis.

In addition to a Ménétrier's disease-like phenotype, MT-TGF $\alpha$ mice develop hyperplasia in the small intestine and colon. Bill Dove et al. recently observed increased tumor multiplicity in the jejunum of MT-TGF $\alpha$ transgenic mice crossed to $A p c^{M i n}$ mice. There was no increase in the size or net growth of established tumors, supporting a role for TGF $\alpha$, like EGFR, in the establishment phase of intestinal neoplasia. Interestingly, MT-TGF $\alpha$ mice exhibited 4-fold less apoptosis in the jejunum than non-transgenic mice. However, the effects of the TGF $\alpha$ transgene on tumor multiplicity in $\mathrm{Ap} \mathrm{CMin}^{\mathrm{Min}}$ mice were region-specific in that no effects on tumor number were observed in the remainder of the small intestine or colon. We are not aware of other transgenic mice overexpressing EGFR ligands that have been crossed to $A p c^{M i n}$ mice. Conversely, epiregulin null mice are the only EGFR ligand-deficient mice that have been crossed to $A p c^{M i n}$ mice; homozygous epiregulin null mice showed a dose-dependent trend toward reduced tumor multiplicity, but it was not statistically significant [82]. 
There is ample preclinical evidence for EGFR contributing to various aspects of colorectal neoplasia. Fidler et al. have proposed that the EGFR in tumor-associated endothelial cells may be the target of the EGFR tyrosine kinase inhibitor [143,144]. EGFR amplification and mutations in the EGFR tyrosine kinase domain occur rarely in colorectal cancer [197]. The frequency of the VIII EGFR variant in colorectal cancer is uncertain; two groups report widely variant results $[145,146]$. These differences may be methodologic in nature; using a newly developed, more sensitive, one-step PCR reaction, Dr. Albert Wong has observed the VIII transcript in 9/16 colorectal tumors [147] (Albert Wong, personal communication).

The EGFR-targeting immunoglobulin IgG1 monoclonal antibody, cetuximab, and the IgG2 monoclonal antibody, panitumumab, are both approved in patients with metastatic CRC. Cetuximab has been shown to be active as a single agent as well as in combination with irinotecan in patients with chemorefractory metastatic CRC [148]. The activity of cetuximab in combination with irinotecan- and oxaliplatin-based therapy in the first-line setting has been demonstrated in phase II studies and a phase III study $[149,150]$. Panitumumab has been shown to be active as single agent in chemorefractory metastatic CRC [151].

However, since only approximately $10 \%$ of patients respond to monotherapy, intense efforts have been devoted to identification of biomarkers that predict responsiveness or nonresponsiveness to these EGFR-neutralizing monoclonal antibodies. Levels of total and phosphorylated EGFR have not proven to be reliable predictors of responsiveness, findings that may reflect the imprecision of the tools available. Conversely, retrospective [152-155] and prospective [156] studies have identified mutant KRAS in CRC as a powerful predictor of non-responsiveness to EGFR mAbs. Wild-type KRAS in CRC appears to be required for responsiveness, although only a small proportion of patients will respond even when this is present $[153,157]$. High levels of amphiregulin and epiregulin mRNA expression in the tumor also predict responsiveness to cetuximab [156]. It appears that patients with mutant KRAS tumors do not exhibit upregulation of amphiregulin or epiregulin; however, only a subset of wild-type KRAS tumors exhibit upregulation of these EGFR ligands [158]. High amphiregulin and epiregulin expression with wild-type KRAS primary CRCs correlates with response and survival benefit after treatment with cetuximab and irinotecan for metastatic disease [158]. Mechanism(s) underlying these observations are unclear. Amongst other possibilities, the sensitivity of these EGFR ligand-overexpressing tumors may reflect "growth factor addiction" by the tumor. It is unclear whether cetuximab resistance is conferred by mutant KRAS itself or by the company it keeps. If due directly to mutant KRAS, it may reflect that RAS is downstream of EGFR, despite preclinical evidence that mutant RAS upregulates EGFR ligands [159].

Using a battery of human colorectal cancer cell lines, Mariadason et al. recently reported that simultaneous activation of RAS and PIK3CA pathways confer maximal resistance to cetuximab. These investigators found that some CRC cell lines with mutant KRAS did respond to cetuximab, a result that is at odds with the preponderance of the clinical data. Other preclinical studies suggest that strategies that target Src [160] and HIF-1 $\alpha$ [161] may work in concert with cetuximab; in the latter case, siRNA knockdown of HIF-1 $\alpha$ was able to restore sensitivity to cetuximab in mutant RAS-transfected A431 cells.

In contrast to cetuximab, the reversible EGFR tyrosine kinase inhibitor gefitinib has little, if any, activity in patients with advanced colorectal cancer [162]. Nevertheless, Baselaga et al. have reported a response to combined iressa and cetuximab in 9/14 individuals with advanced CRC (J. Baselga, personal communication). In addition, in vitro, combined pharmacological blockade of TACE/ADAM-17, ligand uptake and EGFR tyrosine kinase activity resulted in cooperative growth inhibition in HCA-7 cells [17]. 
The role of ErbB2 (HER-2/neu) in CRC is less clear than for EGFR. In 1997, Kapitanovi et al. performed an immunohistochemical analysis of normal colon, hyperplastic polyps, tubular adenomas, tubulovillous adenomas and adenocarcinomas and observed that these tissues differed in their expression of ErbB2 [163]. Only 14\% of normal colons exhibited moderate or strong immunostaining for ErbB2 in contrast to $31 \%$ of hyperplastic polyps, $65 \%$ of tubular adenomas, $100 \%$ of tubulovillous adenomas and $84 \%$ of adenocarcinomas. Furthermore, the intensity of staining among adenocarcinomas correlated with Dukes' stage at diagnosis, metastasis-free survival and post-operative survival. Among tumors initially classified as Dukes' stage A or B which also demonstrated moderate or strong staining for ErbB2, 76\% developed distant metastases during follow-up, and these patients had significantly shorter survival than those with weak staining for ErbB2. In another study, tumors from patients with lymph node metastasis were more likely to exhibit ErbB2 immunostaining than those tumors with no lymph node involvement [164].

Trastuzumab, a monoclonal antibody with activity against ErbB2, has been studied in both in vitro and in vivo models of CRC [165]. Growth of heregrulin-1-stimulated HCA-7 cells was inhibited by both celecoxib and trastuzumab. However, the combination appeared to be more effective than either drug given alone. In Matrigel, trastuzumab alone had little effect on colony number or size, whereas colony size was significantly reduced by the combination of trastuzumab and celecoxib compared to celecoxib alone. Trastuzumab also inhibited the growth of HCA-7 xenografts in nude mice. Again, this effect was more pronounced when used in combination with celecoxib.

However, this high rate of ErbB2 expression has not been observed in other studies. In one Phase II clinical trial, only $8 \%$ of patients screened for HER $2 /$ neu by immunohistochemistry had overexpression demonstrated by moderate or strong staining. Partial responses to treatment with trastuzumab were seen in 5 of 7 evaluable patients, but this study was stopped early due to slow accrual [166]. As a result, there are no large randomized clinical trials evaluating the effectiveness of trastuzumab in the treatment of patients with ErbB2-overexpressing CRCs.

Unlike in the case of breast cancer, the utility of using HER-2 overexpression to predict response to HER-2 inhibition in colorectal cancer has been called into question. It has been observed that the ability of the HER-2 monoclonal antibody 4D5 to inhibit cancer cell proliferation and survival in vitro, or tumorigenicity in vivo, varies by cell line. For example, 4D5 inhibits proliferation in Caco-2 and HCA-7 but not DLD-1 or HT29 cells. Importantly, the relative steady-state expression of HER-2 by immunohistochemistry failed to predict the susceptibility of cancer cell lines to HER-2 inhibition. This may indicate that other methods are needed to predict which patients may be likely to benefit from HER-2 inhibition [167].

Recently, Threadgill et al. have reported that targeted homozygous deletion of Erbb3 in the mouse intestine using villin-Cre mice in combination with floxed Erbb3 results in a more dramatic reduction in tumor burden than homozygous wa2 mice crossed to $A p c^{M i n}$ mice [90]. Although there was a $90 \%$ reduction in tumor multiplicity in both strains, the intestinal tumors were much smaller in ErbB3 Apc ${ }^{\mathrm{Min}}$ mice, and no colonic tumors developed. There was reduced PI3-K/AKT signaling in the tumors with increased caspase3-mediated apoptosis. Loss of ErbB3 in the intestinal epithelium has a much more pronounced antitumor effect than loss of EGFR suggesting that non-EGFR combinations contribute to the majority of tumors (Fig. $3)$.

The role of ErbB4 (HER4) in CRC has not been as well studied as other receptors. In a retrospective immunohistochemical review of 106 colorectal cancers, ErbB4 was expressed at the membrane in $18.9 \%$ and in the cytoplasm in $28.3 \%$. Tumors staining positive for ErbB4 were associated with lymph node involvement, although overall outcomes did not differ 
[168]. Mutations in ErbB4 can occur in CRC but are rare, happening in approximately 2.9\% of cases. All of those detected in one study by Soung et al. were missense mutations [140]. Interestingly, a germline polymorphism in the $5^{\prime}$ promoter region of ErbB4 $(-782 \mathrm{G}>\mathrm{T})$ has been associated with increased risk of CRC (as well as breast cancer). In this study, the G allele showed higher protein binding affinity than the $\mathrm{T}$ allele in competition experiments, and the $\mathrm{T}$ allele had a more than 2.5 -fold decrease in in vitro promoter activity as assessed by reporter gene assays using MDA134 and MDA157 cells for transfection. Taken together, these findings suggest that differences in these observed polymorphisms have implications on ErbB4 promoter activity and may lead to the observed association with CRC [169].

\section{Areas of opportunity}

\section{Ligand delivery/unpeeling the onion}

An understudied area is the cell surface trafficking of EGFR ligands in polarized epithelial cells. This is likely to be physiologically relevant based on the recent observation that isolated recessive renal hypomagnesemia is due to a mutation in the cytoplasmic tail of pro-EGF that disrupts basolateral sorting of pro-EGF [170]. This leads to insufficient stimulation of basolateral EGFRs in the proximal tubule of the kidney, resulting in impaired activation of the $\mathrm{Mg}^{2+}$ channel TRPM6 (transient receptor potential cation channel, subfamily M, member 6) and magnesium wasting in the kidney. We have studied trafficking of EGF, TGF $\alpha$ and amphiregulin in polarized MDCK cells and TGF $\alpha$ and amphiregulin in polarizing colorectal cancer cell lines (reviewed in reference [2]).

The studies with TGF $\alpha$ are the most advanced. We have found that Naked2 acts as a cargo recognition and targeting (CaRT) protein for basolateral delivery of TGF $\alpha$ [171,172]. Naked2 is a member of the Naked family (Naked Cuticle in Drosophila and vertebrate Naked1 and -2) whose members act as antagonists of canonical Wnt signaling. Naked 2 recognizes basolateral sorting motifs in the cytoplasmic tail of Golgi-processed TGF $\alpha$, coats TGF $\alpha$-containing exocytic vesicles and directs these vesicles to the basolateral corner of polarized epithelial cells where the vesicles dock and fuse in a myristoylation-dependent manner (Fig. 4A). In myristoylation-deficient G2ANaked2-expressing MDCK cells, these vesicles are directed to the basolateral surface but are unable to fuse at the basolateral surface, leaving these vesicles (and TGF $\alpha$ ) trapped in the cytoplasm. Amphiregulin, however, is delivered properly to the basolateral surface in these Naked2 mutant cells, suggesting that it uses a different basolateral sorting machinery. We have exploited the trapped nature of these vesicles to biochemically enrich and flow sort G2ANaked2-EGFP vesicles from MDCK cells. By LC/LC-MS/MS, we have identified 389 proteins associated with this subset of basolaterally targeted vesicles [173], thus setting the stage for rapid advances in this field.

Moreover, we have found that TGF $\alpha$ upregulates Naked2 in an EGFR-independent manner [174]. Naked2 is a short-lived protein with a half-life of $1 \mathrm{~h}$ due to constitutive ubiquitinmediated proteasomal degradation by AO7, a ring finger E3 ligase (Fig. 4B). However, upon interacting with the cytoplasmic tail of TGF $\alpha$, Naked 2 is protected from degradation. Thus, TGF $\alpha$ ensures its proper delivery to the basolateral surface of polarized epithelial cells by stabilizing its CaRT Naked2. Recent work indicates that expression of Naked2, in contrast to Naked1 [175], is markedly reduced in over $60 \%$ of CRCs compared to adjacent normal colon (RJ Coffey and W Ding unpublished observation). However, Naked2 levels are maintained in adenomas, a finding that indicates loss of Naked2 is a late event in CRC.

\section{Distinct biological roles among the EGFR ligands}

Ebner and Derynck first reported that EGF and TGF $\alpha$ exhibit clear differences in disposition upon ligand-receptor internalization [176]. Others have reported that the individual EGFR 
ligand determines the specificity of downstream signaling $[27,177,178]$. We have shown that AR, but not TGF $\alpha$, causes an EMT-like phenotype when added to MDCK cells $[179,180]$. Amphiregulin null mice, but not TGF $\alpha$ null mice, develop gastric cancer [181]. The judicious use of overexpression and knockdown strategies of ERBB receptors and cognate ligands in vitro and in vivo should help to elucidate distinct roles for the different ligands.

\section{Stromal epithelial interactions}

It will be informative to examine the relative contribution among ERBBs and their ligands in stromal epithelial crosstalk in the gastrointestinal tract during development and in maintenance of homeostasis in the adult [182]. It is instructive that stromal EGFR is critical for mammary gland development [183].

\section{Conclusion}

The true physiological role of this family of receptors and their cognate ligands will come from understanding their actions in vivo. Reductionist approaches in vitro will continue to be useful, but attempts to use 3D models and reconstitution experiments combining different tissue components (epithelial cells, pericryptal fibroblasts and other tissue elements) will be used increasingly to better simulate in vivo conditions.

\section{Acknowledgments}

The authors thank Declan McCole, Marco Romano, Scott Kuwada, Brad Warner and Albert Wong for helpful discussions and Wei Ding for assistance in the preparation of figures. This work was supported by R01CA092479, U01CA105417 and P50CA106991 to DT and R01CA46413, GI Special Program of Research Excellence (P50CA95103) and Mouse Models of Human Cancers Consortium (U01CA084239) to RJC. RJC also acknowledges the generous support of the Peter Powell Fund.

\section{REFERENCES}

1. Barnard JA, Beauchamp RD, Russell WE, Dubois RN, Coffey RJ. Epidermal growth factor-related peptides and their relevance to gastrointestinal pathophysiology. Gastroenterology 1995;108:564-580. [PubMed: 7835600]

2. Harris RC, Chung E, Coffey RJ. EGF receptor ligands. Exp. Cell Res 2003;284:2-13. [PubMed: 12648462]

3. Korc, M. Biology of pancreatic cancer. In: Rustgi, AK.; Crawford, J., editors. Gastrointestinal Cancers, W. B. Saunders Co.; 2003. p. 519-528.

4. Izeradjene K, Hingorani SR. Targets, trials, and travails in pancreas cancer. J. Natl. Compr. Cancer Netw 2007;5:1042-1053.

5. Tao RH, Maruyama IN. All EGF(ErbB) receptors have preformed homo- and heterodimeric structures in living cells. J. Cell Sci 2008;121:3207-3217. [PubMed: 18782861]

6. Graus-Porta D, Beerli RR, Daly JM, Hynes NE. ErbB-2, the preferred heterodimerization partner of all ErbB receptors, is a mediator of lateral signaling. EMBO J 1997;16:1647-1655. [PubMed: 9130710]

7. Tzahar E, Waterman H, Chen X, Levkowitz G, Karunagaran D, Lavi S, Ratzkin BJ, Yarden Y. A hierarchical network of interreceptor interactions determines signal transduction by Neu differentiation factor/neuregulin and epidermal growth factor. Mol. Cell. Biol 1996;16:5276-5287. [PubMed: 8816440]

8. Higashiyama S, Iwamoto R, Goishi K, Raab G, Taniguchi N, Klagsbrun M, Mekada E. The membrane protein CD9/DRAP 27 potentiates the juxtacrine growth factor activity of the membrane-anchored heparin-binding EGF-like growth factor. J. Cell Biol 1995;128:929-938. [PubMed: 7876316]

9. Iwamoto R, Mekada E. Heparin-binding EGF-like growth factor: a juxtacrine growth factor. Cytokine Growth Factor Rev 2000;11:335-344. [PubMed: 10959080] 
10. Singh AB, Tsukada T, Zent R, Harris RC. Membrane-associated HB-EGF modulates HGF-induced cellular responses in MDCK cells. J. Cell. Sci 2004;117:1365-1379. [PubMed: 14996914]

11. Playford RJ, Hanby AM, Gschmeissner S, Peiffer LP, Wright NA, McGarrity T. The epidermal growth factor receptor (EGF-R) is present on the basolateral, but not the apical, surface of enterocytes in the human gastrointestinal tract. Gut 1996;39:262-266. [PubMed: 8977341]

12. Yarden Y, Sliwkowski MX. Untangling the ErbB signalling network. Nat. Rev. Mol. Cell Biol 2001;2:127-137. [PubMed: 11252954]

13. Chen MC, Solomon TE, Kui R, Soll AH. Apical EGF receptors regulate epithelial barrier to gastric acid: endogenous TGF-alpha is an essential facilitator. Am. J. Physiol 2002;283:G1098-G1106.

14. Sinha A, Nightingale J, West KP, Berlanga-Acosta J, Playford RJ. Epidermal growth factor enemas with oral mesalamine for mild-to-moderate left-sided ulcerative colitis or proctitis. N. Engl. J. Med 2003;349:350-357. [PubMed: 12878742]

15. Playford RJ, Wright NA. Why is epidermal growth factor present in the gut lumen? Gut 1996;38:303305. [PubMed: 8675078]

16. Vermeer PD, Einwalter LA, Moninger TO, Rokhlina T, Kern JA, Zabner J, Welsh MJ. Segregation of receptor and ligand regulates activation of epithelial growth factor receptor. Nature 2003;422:322326. [PubMed: 12646923]

17. Merchant NB, Voskresensky I, Rogers CM, Lafleur B, Dempsey PJ, Graves-Deal R, Revetta F, Foutch AC, Rothenberg ML, Washington MK, Coffey RJ. TACE/ADAM-17: a component of the epidermal growth factor receptor axis and a promising therapeutic target in colorectal cancer. Clin. Cancer Res 2008;14:1182-1191. [PubMed: 18281553]

18. Cartlidge SA, Elder JB. Transforming growth factor alpha and epidermal growth factor levels in normal human gastrointestinal mucosa. Br. J. Cancer 1989;60:657-660. [PubMed: 2803941]

19. Troyer KL, Luetteke NC, Saxon ML, Qiu TH, Xian CJ, Lee DC. Growth retardation, duodenal lesions, and aberrant ileum architecture in triple null mice lacking EGF, amphiregulin, and TGF-alpha. Gastroenterology 2001;121:68-78. [PubMed: 11438495]

20. Moran AE, Hunt DH, Javid SH, Redston M, Carothers AM, Bertagnolli MM. Apc deficiency is associated with increased Egfr activity in the intestinal enterocytes and adenomas of C57BL/6J-Min/ + mice. J. Biol. Chem 2004;279:43261-43272. [PubMed: 15294912]

21. Gangarosa LM, Sizemore N, Graves-Deal R, Oldham SM, Der CJ, Coffey RJ. A raf-independent epidermal growth factor receptor autocrine loop is necessary for Ras transformation of rat intestinal epithelial cells. J. Biol. Chem 1997;272:18926-18931. [PubMed: 9228072]

22. Sato K, Sato A, Aoto M, Fukami Y. c-Src phosphorylates epidermal growth factor receptor on tyrosine 845. Biochem. Biophys. Res. Commun 1995;215:1078-1087. [PubMed: 7488034]

23. Zhang Q, Thomas SM, Lui VW, Xi S, Siegfried JM, Fan H, Smithgall TE, Mills GB, Grandis JR. Phosphorylation of TNF-alpha converting enzyme by gastrin-releasing peptide induces amphiregulin release and EGF receptor activation. Proc. Natl. Acad. Sci. U. S. A 2006;103:6901-6906. [PubMed: 16641105]

24. Jacobs JM, Waters KM, Kathmann LE, Camp DG II, Wiley HS, Smith RD, Thrall BD. The mammary epithelial cell secretome and its regulation by signal transduction pathways. J. Proteome Res 2008;7:558-569. [PubMed: 18166007]

25. Daub H, Weiss FU, Wallasch C, Ullrich A. Role of transactivation of the EGF receptor in signalling by G-protein-coupled receptors. Nature 1996;379:557-560. [PubMed: 8596637]

26. Dong J, Opresko LK, Dempsey PJ, Lauffenburger DA, Coffey RJ, Wiley HS. Metalloproteasemediated ligand release regulates autocrine signaling through the epidermal growth factor receptor. PNAS 1999;96:6235-6240. [PubMed: 10339571]

27. Prenzel N, Zwick E, Daub H, Leserer M, Abraham R, Wallasch C, Ullrich A. EGF receptor transactivation by G-protein-coupled receptors requires metalloproteinase cleavage of proHB-EGF. Nature 1999;402:884-888. [PubMed: 10622253]

28. Ohtsu H, Dempsey PJ, Eguchi S. ADAMs as mediators of EGF receptor transactivation by G proteincoupled receptors. Am. J. Physiol 2006;291:C1-C10.

29. McCole DF, Keely SJ, Coffey RJ, Barrett KE. Transactivation of the epidermal growth factor receptor in colonic epithelial cells by carbachol requires extracellular release of transforming growth factoralpha. J. Biol. Chem 2002;277:42603-42612. [PubMed: 12202486] 
30. McCole DF, Truong A, Bunz M, Barrett KE. Consequences of direct versus indirect activation of epidermal growth factor receptor in intestinal epithelial cells are dictated by protein-tyrosine phosphatase 1B. J. Biol. Chem 2007;282:13303-13315. [PubMed: 17339316]

31. Dempsey PJ, Coffey RJ. Basolateral targeting and efficient consumption of transforming growth factor-alpha when expressed in Madin-Darby canine kidney cells. J. Biol. Chem 1994;269:1687816889. [PubMed: 8207010]

32. van der Merwe JQ, Hollenberg MD, MacNaughton WK. EGF receptor transactivation and MAP kinase mediate proteinase-activated receptor-2-induced chloride secretion in intestinal epithelial cells. Am. J. Physiol 2008;294:G441-G451.

33. Bertelsen LS, Paesold G, Marcus SL, Finlay BB, Eckmann L, Barrett KE. Modulation of chloride secretory responses and barrier function of intestinal epithelial cells by the Salmonella effector protein SigD. Am. J. Physiol 2004;287:C939-C948.

34. McCole DF, Rogler G, Varki N, Barrett KE. Epidermal growth factor partially restores colonic ion transport responses in mouse models of chronic colitis. Gastroenterology 2005;129:591-608. [PubMed: 16083715]

35. Rodland KD, Bollinger N, Ippolito D, Opresko LK, Coffey RJ, Zangar R, Wiley HS. Multiple mechanisms are responsible for transactivation of the epidermal growth factor receptor in mammary epithelial cells. J. Biol. Chem 2008;283:31477-31487. [PubMed: 18782770]

36. Pai R, Nakamura T, Moon WS, Tarnawski AS. Prostaglandins promote colon cancer cell invasion; signaling by cross-talk between two distinct growth factor receptors. FASEB J 2003;17:1640-1647. [PubMed: 12958170]

37. Shao J, Lee SB, Guo H, Evers BM, Sheng H. Prostaglandin E2 stimulates the growth of colon cancer cells via induction of amphiregulin. Cancer Res 2003;63:5218-5223. [PubMed: 14500348]

38. Bhola NE, Grandis JR. Crosstalk between G-protein-coupled receptors and epidermal growth factor receptor in cancer. Front. Biosci 2008;13:1857-1865. [PubMed: 17981673]

39. Lautrette A, Li S, Alili R, Sunnarborg SW, Burtin M, Lee DC, Friedlander G, Terzi F. Angiotensin II and EGF receptor cross-talk in chronic kidney diseases: a new therapeutic approach. Nature Med 2005;11:867-874. [PubMed: 16041383]

40. Coffey RJ Jr. Derynck R, Wilcox JN, Bringman TS, Goustin AS, Moses HL, Pittelkow MR. Production and auto-induction of transforming growth factor-alpha in human keratinocytes. Nature 1987;328:817-820. [PubMed: 2442615]

41. Barnard JA, Graves-Deal R, Pittelkow MR, DuBois R, Cook P, Ramsey GW, Bishop PR, Damstrup L, Coffey RJ. Auto- and cross-induction within the mammalian epidermal growth factor-related peptide family. J. Biol. Chem 1994;269:22817-22822. [PubMed: 8077234]

42. Weihua Z, Tsan R, Huang WC, Wu Q, Chiu CH, Fidler IJ, Hung MC. Survival of cancer cells is maintained by EGFR independent of its kinase activity. Cancer Cell 2008;13:385-393. [PubMed: 18455122]

43. Santiskulvong C, Rozengurt E. Protein kinase Calpha mediates feedback inhibition of EGF receptor transactivation induced by Gq-coupled receptor agonists. Cell. Signal 2007;19:1348-1357. [PubMed: 17307332]

44. Crotty T, Cai J, Sakane F, Taketomi A, Prescott SM, Topham MK. Diacylglycerol kinase delta regulates protein kinase $\mathrm{C}$ and epidermal growth factor receptor signaling. Proc. Natl. Acad. Sci. U. S. A 2006;103:15485-15490. [PubMed: 17021016]

45. Oster H, Leitges M. Protein kinase $\mathrm{C}$ alpha but not PKCzeta suppresses intestinal tumor formation in ApcMin/+ mice. Cancer Res 2006;66:6955-6963. [PubMed: 16849539]

46. Roxas JL, Koutsouris A, Viswanathan VK. Enteropathogenic Escherichia coli-induced epidermal growth factor receptor activation contributes to physiological alterations in intestinal epithelial cells. Infect. Immun 2007;75:2316-2324. [PubMed: 17339360]

47. Buret A, Olson ME, Gall DG, Hardin JA. Effects of orally administered epidermal growth factor on enteropathogenic Escherichia coli infection in rabbits. Infect. Immun 1998;66:4917-4923. [PubMed: 9746597]

48. Palmer LM, Reilly TJ, Utsalo SJ, Donnenberg MS. Internalization of Escherichia coli by human renal epithelial cells is associated with tyrosine phosphorylation of specific host cell proteins. Infect. Immun 1997;65:2570-2575. [PubMed: 9199421] 
49. Zhang J, Li H, Wang J, Dong Z, Mian S, Yu FS. Role of EGFR transactivation in preventing apoptosis in Pseudomonas aeruginosa-infected human corneal epithelial cells. Invest. Ophthalmol. Vis. Sci 2004;45:2569-2576. [PubMed: 15277479]

50. Na X, Zhao D, Koon HW, Kim H, Husmark J, Moyer MP, Pothoulakis C, LaMont JT. Clostridium difficile toxin $\mathrm{B}$ activates the EGF receptor and the ERK/MAP kinase pathway in human colonocytes. Gastroenterology 2005;128:1002-1011. [PubMed: 15825081]

51. Galan JE, Pace J, Hayman MJ. Involvement of the epidermal growth factor receptor in the invasion of cultured mammalian cells by Salmonella typhimurium. Nature 1992;357:588-589. [PubMed: 1608468]

52. McNeil A, Dunstan SJ, Clark S, Strugnell RA. Salmonella typhimurium displays normal invasion of mice with defective epidermal growth factor receptors. Infect. Immun 1995;63:2770-2772. [PubMed: 7790097]

53. Wang X, Huong SM, Chiu ML, Raab-Traub N, Huang ES. Epidermal growth factor receptor is a cellular receptor for human cytomegalovirus. Nature 2003;424:456-461. [PubMed: 12879076]

54. Boyle KA, Pietropaolo RL, Compton T. Engagement of the cellular receptor for glycoprotein B of human cytomegalovirus activates the interferon-responsive pathway. Mol. Cell. Biol 1999;19:36073613. [PubMed: 10207084]

55. Johnson RA, Huong SM, Huang ES. Activation of the mitogen-activated protein kinase $\mathrm{p} 38$ by human cytomegalovirus infection through two distinct pathways: a novel mechanism for activation of $\mathrm{p} 38$. J. Virol 2000;74:1158-1167. [PubMed: 10627526]

56. Johnson RA, Wang X, Ma XL, Huong SM, Huang ES. Human cytomegalovirus up-regulates the phosphatidylinositol 3-kinase (PI3-K) pathway: inhibition of PI3-K activity inhibits viral replication and virus-induced signaling. J. Virol 2001;75:6022-6032. [PubMed: 11390604]

57. Isaacson MK, Feire AL, Compton T. Epidermal growth factor receptor is not required for human cytomegalovirus entry or signaling. J. Virol 2007;81:6241-6247. [PubMed: 17428848]

58. Everhart JE. Recent developments in the epidemiology of Helicobacter pylori. Gastroenterol. Clin. North Am 2000;29:559-578. [PubMed: 11030073]

59. Marshall BJ, Goodwin CS, Warren JR, Murray R, Blincow ED, Blackbourn SJ, Phillips M, Waters TE, Sanderson CR. Prospective double-blind trial of duodenal ulcer relapse after eradication of Campylobacter pylori. Lancet 1988;2:1437-1442. [PubMed: 2904568]

60. Logan RP, Gummett PA, Misiewicz JJ, Karim QN, Walker MM, Baron JH. One week eradication regimen for Helicobacter pylori. Lancet 1991;338:1249-1252. [PubMed: 1682653]

61. Graham DY, Lew GM, Klein PD, Evans DG, Evans DJ Jr. Saeed ZA, Malaty HM. Effect of treatment of Helicobacter pylori infection on the long-term recurrence of gastric or duodenal ulcer. A randomized, controlled study. Ann. Intern. Med 1992;116:705-708. [PubMed: 1558340]

62. Huang JQ, Sridhar S, Chen Y, Hunt RH. Meta-analysis of the relationship between Helicobacter pylori seropositivity and gastric cancer. Gastroenterology 1998;114:1169-1179. [PubMed: 9609753]

63. Parsonnet J, Friedman GD, Vandersteen DP, Chang Y, Vogelman JH, Orentreich N, Sibley RK. Helicobacter pylori infection and the risk of gastric carcinoma. N. Engl. J. Med 1991;325:11271131. [PubMed: 1891020]

64. Keates S, Keates AC, Katchar K, Peek RM Jr. Kelly CP. Helicobacter pylori induces up-regulation of the epidermal growth factor receptor in AGS gastric epithelial cells. J. Infect. Dis 2007;196:95103. [PubMed: 17538889]

65. Wallasch C, Crabtree JE, Bevec D, Robinson PA, Wagner H, Ullrich A. Helicobacter pyloristimulated EGF receptor transactivation requires metalloprotease cleavage of HB-EGF. Biochem. Biophys. Res. Commun 2002;295:695-701. [PubMed: 12099696]

66. Romano M, Ricci V, Di Popolo A, Sommi P, Del Vecchio Blanco C, Bruni CB, Ventura U, Cover TL, Blaser MJ, Coffey RJ, Zarrilli R. Helicobacter pylori upregulates expression of epidermal growth factor-related peptides, but inhibits their proliferative effect in MKN 28 gastric mucosal cells. J. Clin. Invest 1998;101:1604-1613. [PubMed: 9541490]

67. Keates S, Sougioultzis S, Keates AC, Zhao D, Peek RM Jr. Shaw LM, Kelly CP. cag+ Helicobacter pylori induce transactivation of the epidermal growth factor receptor in AGS gastric epithelial cells. J. Biol. Chem 2001;276:48127-48134. [PubMed: 11604402] 
68. Caputo R, Tuccillo C, Manzo BA, Zarrilli R, Tortora G, Blanco Cdel V, Ricci V, Ciardiello F, Romano M. Helicobacter pylori VacA toxin up-regulates vascular endothelial growth factor expression in MKN 28 gastric cells through an epidermal growth factor receptor-, cyclooxygenase-2-dependent mechanism. Clin. Cancer Res 2003;9:2015-2021. [PubMed: 12796363]

69. Busiello I, Acquaviva R, Di Popolo A, Blanchard TG, Ricci V, Romano M, Zarrilli R. Helicobacter pylori gamma-glutamyltranspeptidase upregulates COX-2 and EGF-related peptide expression in human gastric cells. Cell. Microbiol 2004;6:255-267. [PubMed: 14764109]

70. Schiemann U, Konturek JW, Osterhoff M, Assert R, Rembiasz K, Pfeiffer D, Schatz H, Domschke W, Pfeiffer A. Decreased expression of epidermal growth factor receptor and mRNA of its ligands in Helicobacter pylori-infected gastric mucosa. Scand. J. Gastroenterol 2001;36:23-31. [PubMed: 11218236]

71. Cox JM, Clayton CL, Tomita T, Wallace DM, Robinson PA, Crabtree JE. cDNA array analysis of cag pathogenicity island-associated Helicobacter pylori epithelial cell response genes. Infect. Immun 2001;69:6970-6980. [PubMed: 11598072]

72. Tuccillo C, Manzo BA, Nardone G, D'Argenio G, Rocco A, Di Popolo A, Della VN, Staibano S, De Rosa G, Ricci V, Del Vecchio BC, Zarrilli R, Romano M. Up-regulation of heparin binding epidermal growth factor-like growth factor and amphiregulin expression in Helicobacter pylori-infected human gastric mucosa. Dig. Liver Dis 2002;34:498-505. [PubMed: 12236483]

73. Persico M, Suozzo R, Zarrilli R, Ricci V, Tuccillo C, Romano M. Decreased gastroduodenal mucosal concentration of transforming growth factor-alpha in Helicobacter pylori-infected dyspeptic patients. Am. J. Gastroenterol 1998;93:2643-2644. [PubMed: 9860467]

74. Peek RM Jr. Crabtree JE. Helicobacter infection and gastric neoplasia. J. Pathol 2006;208:233-248. [PubMed: 16362989]

75. Mitamura T, Higashiyama S, Taniguchi N, Klagsbrun M, Mekada E. Diphtheria toxin binds to the epidermal growth factor (EGF)-like domain of human heparin-binding EGF-like growth factor/ diphtheria toxin receptor and inhibits specifically its mitogenic activity. J. Biol. Chem 1995;270:1015-1019. [PubMed: 7836353]

76. Threadgill DW, Dlugosz AA, Hansen LA, Tennenbaum T, Lichti U, Yee D, LaMantia C, Mourton T, Herrup K, Harris RC, Barnard JA, Yuspa SH, Coffey RJ, Magnuson T. Targeted disruption of mouse EGF receptor: effect of genetic background on mutant phenotype. Science 1995;269:230234. [PubMed: 7618084]

77. Miettinen PJ, Berger JE, Meneses J, Phung Y, Pedersen RA, Werb Z, Derynck R. Epithelial immaturity and multiorgan failure in mice lacking epidermal growth factor receptor. Nature 1995;376:337-341. [PubMed: 7630400]

78. Nair RR, Warner BB, Warner BW. Role of epidermal growth factor and other growth factors in the prevention of necrotizing enterocolitis. Semin. Perinatol 2008;32:107-113. [PubMed: 18346534]

79. Yu, M.; Lee, TC.; Threadgill, DW. Conditional ablation of EGFR in the intestinal epithelium identifies an EGFR-independent pathway for colorectal cancer growth. (Submitted for publication)

80. Egger B, Buchler MW, Lakshmanan J, Moore P, Eysselein VE. Mice harboring a defective epidermal growth factor receptor (waved-2) have an increased susceptibility to acute dextran sulfate-induced colitis. Scand. J. Gastroenterol 2000;35:1181-1187. [PubMed: 11145290]

81. Egger B, Procaccino F, Lakshmanan J, Reinshagen M, Hoffmann P, Patel A, Reuben W, Gnanakkan S, Liu L, Barajas L, Eysselein VE. Mice lacking transforming growth factor alpha have an increased susceptibility to dextran sulfate-induced colitis. Gastroenterology 1997;113:825-832. [PubMed: 9287974]

82. Lee D, Pearsall RS, Das S, Dey SK, Godfrey VL, Threadgill DW. Epiregulin is not essential for development of intestinal tumors but is required for protection from intestinal damage. Mol. Cell. Biol 2004;24:8907-8916. [PubMed: 15456865]

83. Egger B, Carey HV, Procaccino F, Chai NN, Sandgren EP, Lakshmanan J, Buslon VS, French SW, Buchler MW, Eysselein VE. Reduced susceptibility of mice overexpressing transforming growth factor alpha to dextran sodium sulphate induced colitis. Gut 1998;43:64-70. [PubMed: 9771407]

84. Helmrath MA, Erwin CR, Warner BW. A defective EGF-receptor in waved-2 mice attenuates intestinal adaptation. J. Surg. Res 1997;69:76-80. [PubMed: 9202650] 
85. Jarboe MD, Juno RJ, Bernal NP, Knott AW, Zhang Y, Erwin CR, Warner BW. Bax deficiency rescues resection-induced enterocyte apoptosis in mice with perturbed EGF receptor function. Surgery 2004;136:121-126. [PubMed: 15300170]

86. Erwin CR, Helmrath MA, Shin CE, Falcone RA Jr. Stern LE, Warner BW. Intestinal overexpression of EGF in transgenic mice enhances adaptation after small bowel resection. Am. J. Physiol 1999;277:G533-G540. [PubMed: 10484377]

87. Falcone RA Jr. Stern LE, Kemp CJ, Erwin CR, Warner BW. Intestinal adaptation occurs independent of transforming growth factor-alpha. J. Pediatr. Surg 2000;35:365-370. [PubMed: 10693698]

88. Gassmann M, Casagranda F, Orioli D, Simon H, Lai C, Klein R, Lemke G. Aberrant neural and cardiac development in mice lacking the ErbB4 neuregulin receptor. Nature 1995;378:390-394. [PubMed: 7477376]

89. Lee KF, Simon H, Chen H, Bates B, Hung MC, Hauser C. Requirement for neuregulin receptor erbB2 in neural and cardiac development. Nature 1995;378:394-398. [PubMed: 7477377]

90. Lee DK, Yu M, Kim H, Paniccia C, Kurie JM, Threadgill DW. Tumor-specific apoptosis caused by deletion of the ERBB3 pseudo-kinase in the intestinal epithelium. JCI. (in press).

91. Gibault L, Metges JP, Conan-Charlet V, Lozac'h P, Robaszkiewicz M, Bessaguet C, Lagarde N, Volant A. Diffuse EGFR staining is associated with reduced overall survival in locally advanced oesophageal squamous cell cancer. Br. J. Cancer 2005;93:107-115. [PubMed: 15986037]

92. Yano H, Shiozaki H, Kobayashi K, Yano T, Tahara H, Tamura S, Mori T. Immunohistologic detection of the epidermal growth factor receptor in human esophageal squamous cell carcinoma. Cancer 1991;67:91-98. [PubMed: 1702347]

93. Itakura Y, Sasano H, Shiga C, Furukawa Y, Shiga K, Mori S, Nagura H. Epidermal growth factor receptor overexpression in esophageal carcinoma. An immunohistochemical study correlated with clinicopathologic findings and DNA amplification. Cancer 1994;74:795-804. [PubMed: 8039107]

94. Andl CD, Mizushima T, Nakagawa H, Oyama K, Harada H, Chruma K, Herlyn M, Rustgi AK. Epidermal growth factor receptor mediates increased cell proliferation, migration, and aggregation in esophageal keratinocytes in vitro and in vivo. J. Biol. Chem 2003;278:1824-1830. [PubMed: 12435727]

95. Andl CD, Mizushima T, Oyama K, Bowser M, Nakagawa H, Rustgi AK. EGFR-induced cell migration is mediated predominantly by the JAK-STAT pathway in primary esophageal keratinocytes. Am. J. Physiol. Gasterointest. Liver Physiol 2004;287:G1227-G1237.

96. Okawa T, Michaylira CZ, Kalabis J, Stairs DB, Nakagawa H, Andl CD, Johnstone CN, Klein-Szanto AJ, El-Deiry WS, Cukierman E, Herlyn M, Rustgi AK. The functional interplay between EGFR overexpression, hTERT activation, and p53 mutation in esophageal epithelial cells with activation of stromal fibroblasts induces tumor development, invasion, and differentiation. Genes Dev 2007;21:2788-2803. [PubMed: 17974918]

97. Wang KL, Wu TT, Choi IS, Wang H, Reseetkova E, Correa AM, Hofstetter WL, Swisher SG, Ajani JA, Rashid A, Albarracin CT. Expression of epidermal growth factor receptor in esophageal and esophagogastric junction adenocarcinomas: association with poor outcome. Cancer 2007;109:658667. [PubMed: 17211865]

98. Kwak EL, Jankowski J, Thayer SP, Lauwers GY, Brannigan BW, Harris PL, Okimoto RA, Haserlat SM, Driscoll DR, Ferry D, Muir B, Settleman J, Fuchs CS, Kulke MH, Ryan DP, Clark JW, Sgroi DC, Haber DA, Bell DW. Epidermal growth factor receptor kinase domain mutations in esophageal and pancreatic adenocarcinomas. Clin. Cancer Res 2006;12:4283-4287. [PubMed: 16857803]

99. Lynch TJ, Bell DW, Sordella R, Gurubhagavatula S, Okimoto RA, Brannigan BW, Harris PL, Haserlat SM, Supko JG, Haluska FG, Louis DN, Christiani DC, Settleman J, Haber DA. Activating mutations in the epidermal growth factor receptor underlying responsiveness of non-small-cell lung cancer to gefitinib. N. Engl. J. Med 2004;350:2129-2139. [PubMed: 15118073]

100. Paez JG, Janne PA, Lee JC, Tracy S, Greulich H, Gabriel S, Herman P, Kaye FJ, Lindeman N, Boggon TJ, Naoki K, Sasaki H, Fujii Y, Eck MJ, Sellers WR, Johnson BE, Meyerson M. EGFR mutations in lung cancer: correlation with clinical response to gefitinib therapy. Science 2004;304:1497-1500. [PubMed: 15118125]

101. Pao W, Miller V, Zakowski M, Doherty J, Politi K, Sarkaria I, Singh B, Heelan R, Rusch V, Fulton L, Mardis E, Kupfer D, Wilson R, Kris M, Varmus H. EGF receptor gene mutations are common 
in lung cancers from "never smokers" and are associated with sensitivity of tumors to gefitinib and erlotinib. Proc. Natl. Acad. Sci. U. S. A 2004;101:13306-13311. [PubMed: 15329413]

102. Shigematsu H, Lin L, Takahashi T, Nomura M, Suzuki M, Wistuba, Fong KM, Lee H, Toyooka S, Shimizu N, Fujisawa T, Feng Z, Roth JA, Herz J, Minna JD, Gazdar AF. Clinical and biological features associated with epidermal growth factor receptor gene mutations in lung cancers. J. Natl. Cancer Inst 2005;97:339-346. [PubMed: 15741570]

103. Lanas AI, Blas JM, Ortego J, Soria J, Sainz R. Adaptation of esophageal mucosa to acid- and pepsininduced damage: role of nitric oxide and epidermal growth factor. Dig. Dis. Sci 1997;42:10031012. [PubMed: 9149055]

104. Fujiwara Y, Higuchi K, Hamaguchi M, Takashima T, Watanabe T, Tominaga K, Oshitani N, Matsumoto T, Arakawa T. Increased expression of transforming growth factor-alpha and epidermal growth factor receptors in rat chronic reflux esophagitis. J. Gastroenterol. Hepatol 2004;19:521527. [PubMed: 15086595]

105. Lagergren J, Bergstrom R, Lindgren A, Nyren O. Symptomatic gastroesophageal reflux as a risk factor for esophageal adenocarcinoma. N. Engl. J. Med 1999;340:825-831. [PubMed: 10080844]

106. Miller CT, Moy JR, Lin L, Schipper M, Normolle D, Brenner DE, Iannettoni MD, Orringer MB, Beer DG. Gene amplification in esophageal adenocarcinomas and Barrett's with high-grade dysplasia. Clin. Cancer Res 2003;9:4819-4825. [PubMed: 14581353]

107. Walch A, Specht K, Braselmann H, Stein H, Siewert JR, Hopt U, Hofler H, Werner M. Coamplification and coexpression of GRB7 and ERBB2 is found in high grade intraepithelial neoplasia and in invasive Barrett's carcinoma. Int. J. Cancer 2004;112:747-753. [PubMed: 15386389]

108. Brien TP, Odze RD, Sheehan CE, McKenna BJ, Ross JS. HER-2/neu gene amplification by FISH predicts poor survival in Barrett's esophagus-associated adenocarcinoma. Human Pathol 2000;31:35-39. [PubMed: 10665910]

109. Safran H, Dipetrillo T, Akerman P, Ng T, Evans D, Steinhoff M, Benton D, Purviance J, Goldstein L, Tantravahi U, Kennedy T. Phase I/II study of trastuzumab, paclitaxel, cisplatin and radiation for locally advanced, HER2 overexpressing, esophageal adenocarcinoma. Int. J. Radiat. Oncol. Biol. Phys 2007;67:405-409. [PubMed: 17097832]

110. Peng D, Sheta EA, Powell SM, Moskaluk CA, Washington K, Goldknopf IL, El-Rifai W. Alterations in Barrett's-related adenocarcinomas: a proteomic approach. Int. J. Cancer 2008;122:1303-1310. [PubMed: 18000824]

111. Kataoka H, Joh T, Kasugai K, Okayama N, Moriyama A, Asai K, Kato T. Expression of mRNA for heregulin and its receptor, ErbB-3 and ErbB-4, in human upper gastrointestinal mucosa. Life Sci 1998;63:553-564. [PubMed: 9718081]

112. Coffey RJ, Washington MK, Corless CL, Heinrich MC. Menetrier disease and gastrointestinal stromal tumors: hyperproliferative disorders of the stomach. J. Clin. Invest 2007;117:70-80. [PubMed: 17200708]

113. Barbosa AJ, Nogueira AM, Leite VH, Lima Junior GF, Oliveira CA. Parietal cell carcinoma of the stomach and Menetrier's disease. Arq. Gastroenterol 1987;24:36-40. [PubMed: 3450269]

114. Charton-Bain MC, Paraf F, Bruneval P. Superficial gastric carcinoma developed on localized hypertrophic lymphocytic gastritis: a variant of localized Menetrier's disease? Pathol. Res. Pract 2000;196:125-128. [PubMed: 10707370]

115. Choi SB, Park SS, Oh SY, Kim JH, Kim WB, Lee JH, Choi JW, Kim SJ, Kim CS, Mok YJ. Primary squamous cell carcinoma of the stomach that developed with Menetrier's disease. Dig. Dis. Sci 2007;52:1722-1724. [PubMed: 17443414]

116. Hsu CT, Ito M, Kawase Y, Sekine I, Ohmagari T, Hashimoto S. Early gastric cancer arising from localized Menetrier's disease. Gastroenterol. Jpn 1991;26:213-217. [PubMed: 1645687]

117. Johnson MI, Spark JI, Ambrose NS, Wyatt JI. Early gastric cancer in a patient with Menetrier's disease, lymphocytic gastritis and Helicobacter pylori. Eur. J. Gastroenterol. Hepatol 1995;7:187190. [PubMed: 7712313]

118. Wood MG, Bates C, Brown RC, Losowsky MS. Intramucosal carcinoma of the gastric antrum complicating Menetrier's disease. J. Clin. Pathol 1983;36:1071-1075. [PubMed: 6886023] 
119. Coffey RJ, Romano M, Goldenring J. Roles for transforming growth factor-alpha in the stomach. J. Clin. Gastroenterol 1995;21(Suppl. 1):S36-S39. [PubMed: 8774988]

120. Dempsey PJ, Goldenring JR, Soroka CJ, Modlin IM, McClure RW, Lind CD, Ahlquist DA, Pittelkow MR, Lee DC, Sandgren EP, Page DL, Coffey RJ. Possible role of transforming growth factor alpha in the pathogenesis of Menetrier's disease: supportive evidence form humans and transgenic mice. Gastroenterology 1992;103:1950-1963. [PubMed: 1451986]

121. Coffey RJ, Romano M, Polk WH, Dempsey PJ. Roles for transforming growth factor-alpha in gastric physiology and pathophysiology. Yale J. Biol. Med 1992;65:693-704. discussion 621-693. [PubMed: 1341072]

122. Bluth RF, Carpenter HA, Pittelkow MR, Page DL, Coffey RJ. Immunolocalization of transforming growth factor-alpha in normal and diseased human gastric mucosa. Human Pathol 1995;26:13331340. [PubMed: 8522306]

123. Settle SH, Washington K, Lind C, Itzkowitz S, Fiske WH, Burdick JS, Jerome WG, Ray M, Weinstein W, Coffey RJ. Chronic treatment of Menetrier's disease with Erbitux: clinical efficacy and insight into pathophysiology. Clin. Gastroenterol. Hepatol 2005;3:654-659. [PubMed: 16206497]

124. Tokunaga A, Onda M, Okuda T, Teramoto T, Fujita I, Mizutani T, Kiyama T, Yoshiyuki T, Nishi $\mathrm{K}$, Matsukura N. Clinical significance of epidermal growth factor (EGF), EGF receptor, and cerbB-2 in human gastric cancer. Cancer 1995;75:1418-1425. [PubMed: 7889468]

125. Takehana T, Kunitomo K, Suzuki S, Kono K, Fujii H, Matsumoto Y, Ooi A. Expression of epidermal growth factor receptor in gastric carcinomas. Clin. Gastroenterol. Hepatol 2003;1:438-445. [PubMed: 15017643]

126. Teramoto T, Onda M, Tokunaga A, Asano G. Inhibitory effect of anti-epidermal growth factor receptor antibody on a human gastric cancer. Cancer 1996;77:1639-1645. [PubMed: 8608556]

127. Pinto C, Di Fabio F, Siena S, Cascinu S, Rojas Llimpe FL, Ceccarelli C, Mutri V, Giannetta L, Giaquinta S, Funaioli C, Berardi R, Longobardi C, Piana E, Martoni AA. Phase II study of cetuximab in combination with FOLFIRI in patients with untreated advanced gastric or gastroesophageal junction adenocarcinoma (FOLCETUX study). Ann. Oncol 2007;18:510-517. [PubMed: 17164226]

128. Mizutani T, Onda M, Tokunaga A, Yamanaka N, Sugisaki Y. Relationship of C-erbB-2 protein expression and gene amplification to invasion and metastasis in human gastric cancer. Cancer 1993;72:2083-2088. [PubMed: 8397058]

129. Park JB, Rhim JS, Park SC, Kimm SW, Kraus MH. Amplification, overexpression, and rearrangement of the erbB-2 protooncogene in primary human stomach carcinomas. Cancer Res 1989;49:6605-6609. [PubMed: 2573419]

130. Tanner M, Hollmen M, Junttila TT, Kapanen AI, Tommola S, Soini Y, Helin H, Salo J, Joensuu H, Sihvo E, Elenius K, Isola J. Amplification of HER-2 in gastric carcinoma: association with topoisomerase IIalpha gene amplification, intestinal type, poor prognosis and sensitivity to trastuzumab. Ann. Oncol 2005;16:273-278. [PubMed: 15668283]

131. Nakajima M, Sawada H, Yamada Y, Watanabe A, Tatsumi M, Yamashita J, Matsuda M, Sakaguchi T, Hirao T, Nakano H. The prognostic significance of amplification and overexpression of c-met and c-erb B-2 in human gastric carcinomas. Cancer 1999;85:1894-1902. [PubMed: 10223227]

132. Park DI, Yun JW, Park JH, Oh SJ, Kim HJ, Cho YK, Sohn CI, Jeon WK, Kim BI, Yoo CH, Son BH, Cho EY, Chae SW, Kim EJ, Sohn JH, Ryu SH, Sepulveda AR. HER-2/neu amplification is an independent prognostic factor in gastric cancer. Dig. Dis. Sci 2006;51:1371-1379. [PubMed: 16868827]

133. Yonemura Y, Ninomiya I, Ohoyama S, Kimura H, Yamaguchi A, Fushida S, Kosaka T, Miwa K, Miyazaki I, Endou Y, Tanaka M, Sasaki T, Kosaka T, Miwa K. Expression of c-erbB-2 oncoprotein in gastric carcinoma. Immunoreactivity for c-erbB-2 protein is an independent indicator of poor short-term prognosis in patients with gastric carcinoma. Cancer 1991;67:2914-2918. [PubMed: 1673870]

134. Kim SY, Kim HP, Kim YJ, Oh do Y, Im SA, Lee D, Jong HS, Kim TY, Bang YJ. Trastuzumab inhibits the growth of human gastric cancer cell lines with HER2 amplification synergistically with cisplatin. Int. J. Oncol 2008;32:89-95. [PubMed: 18097546] 
135. Matsui Y, Inomata M, Tojigamori M, Sonoda K, Shiraishi N, Kitano S. Suppression of tumor growth in human gastric cancer with HER2 overexpression by an anti-HER2 antibody in a murine model. Int. J. Oncol 2005;27:681-685. [PubMed: 16077916]

136. Fujimoto-Ouchi K, Sekiguchi F, Yasuno H, Moriya Y, Mori K, Tanaka Y. Antitumor activity of trastuzumab in combination with chemotherapy in human gastric cancer xenograft models. Cancer Chemother. Pharmacol 2007;59:795-805. [PubMed: 17031648]

137. Inui T, Asakawa A, Morita Y, Mizuno S, Natori T, Kawaguchi A, Murakami M, Hishikawa Y, Inui A. HER-2 overexpression and targeted treatment by trastuzumab in a very old patient with gastric cancer. J. Intern. Med 2006;260:484-487. [PubMed: 17040255]

138. Rebischung C, Barnoud R, Stefani L, Faucheron JL, Mousseau M. The effectiveness of trastuzumab (Herceptin) combined with chemotherapy for gastric carcinoma with overexpression of the c-erbB-2 protein. Gastric Cancer 2005;8:249-252. [PubMed: 16328600]

139. Kobayashi M, Iwamatsu A, Shinohara-Kanda A, Ihara S, Fukui Y. Activation of ErbB3-PI3-kinase pathway is correlated with malignant phenotypes of adenocarcinomas. Oncogene 2003;22:12941301. [PubMed: 12618754]

140. Soung YH, Lee JW, Kim SY, Wang YP, Jo KH, Moon SW, Park WS, Nam SW, Lee JY, Yoo NJ, Lee SH. Somatic mutations of the ERBB4 kinase domain in human cancers. Int. J. Cancer 2006;118:1426-1429. [PubMed: 16187281]

141. Roberts RB, Min L, Washington MK, Olsen SJ, Settle SH, Coffey RJ, Threadgill DW. Importance of epidermal growth factor receptor signaling in establishment of adenomas and maintenance of carcinomas during intestinal tumorigenesis. Proc. Natl. Acad. Sci. U. S. A 2002;99:1521-1526. [PubMed: 11818567]

142. Fichera A, Little N, Jagadeeswaran S, Dougherty U, Sehdev A, Mustafi R, Cerda S, Yuan W, Khare S, Tretiakova M, Gong C, Tallerico M, Cohen G, Joseph L, Hart J, Turner JR, Bissonnette M. Epidermal growth factor receptor signaling is required for microadenoma formation in the mouse azoxymethane model of colonic carcinogenesis. Cancer Res 2007;67:827-835. [PubMed: 17234795]

143. Kuwai T, Nakamura T, Sasaki T, Kim SJ, Fan D, Villares GJ, Zigler M, Wang H, Bar-Eli M, Kerbel RS, Fidler IJ. Phosphorylated epidermal growth factor receptor on tumor-associated endothelial cells is a primary target for therapy with tyrosine kinase inhibitors. Neoplasia (New York, N.Y.) 2008;10:489-500.

144. Sasaki T, Nakamura T, Rebhun RB, Cheng H, Hale KS, Tsan RZ, Fidler IJ, Langley RR. Modification of the primary tumor microenvironment by transforming growth factor alphaepidermal growth factor receptor signaling promotes metastasis in an orthotopic colon cancer model. Am. J. Pathol 2008;173:205-216. [PubMed: 18583324]

145. Cunningham MP, Essapen S, Thomas H, Green M, Lovell DP, Topham C, Marks C, Modjtahedi H. Coexpression, prognostic significance and predictive value of EGFR, EGFRvIII and phosphorylated EGFR in colorectal cancer. Int. J. Oncol 2005;27:317-325. [PubMed: 16010411]

146. Azuma M, Danenberg KD, Iqbal S, El-Khoueiry A, Zhang W, Yang D, Koizumi W, Saigenji K, Danenberg PV, Lenz HJ. Epidermal growth factor receptor and epidermal growth factor receptor variant III gene expression in metastatic colorectal cancer. Clin. Colorectal Cancer 2006;6:214218. [PubMed: 17026791]

147. Wong, A. personal communication.

148. Cunningham D, Humblet Y, Siena S, Khayat D, Bleiberg H, Santoro A, Bets D, Mueser M, Harstrick A, Verslype C, Chau I, Van Cutsem E. Cetuximab monotherapy and cetuximab plus irinotecan in irinotecan-refractory metastatic colorectal cancer. N. Engl. J. Med 2004;351:337-345. [PubMed: 15269313]

149. Bockemeyer, C.; Bondarwnko, I.; Hartman, J.; De Braud, FG.; Volovat, C.; Nippgen, J.; Stroh, C.; Celik, I.; Koralewski, P. KRAS status and efficacy of first-line treatment of patients with metastatic colorectal cancer with FOLFOX with or without cetuximab: the OPUS experience. J. Clin. Oncol; ASCO Annual Meeting; 2008. (May 20 suppl; abstr 4000)

150. Van Cutsem, E.; Lang, I.; D'Haens, G.; Moiseyenko, V.; Zaluski, J.; Folprecht, G.; Tejpar, S.; Kisker, O.; Stroh, C.; Rougier, P. KRAS status and efficacy in the first-line treatment of patients with metastatic colorectal cancer treated with or without cetuximab: the CRYSTAL experience. ASCO Annual Meeting; 2008. 
151. Van Cutsem E, Peeters M, Siena S, Humblet Y, Hendlisz A, Neyns B, Canon JL, Van Laethem JL, Maurel J, Richardson G, Wolf M, Amado RG. Open-label phase III trial of panitumumab plus best supportive care compared with best supportive care alone in patients with chemotherapy-refractory metastatic colorectal cancer. J. Clin. Oncol 2007;25:1658-1664. [PubMed: 17470858]

152. Benvenuti S, Sartore-Bianchi A, Di Nicolantonio F, Zanon C, Moroni M, Veronese S, Siena S, Bardelli A. Oncogenic activation of the RAS/RAF signaling pathway impairs the response of metastatic colorectal cancers to anti-epidermal growth factor receptor antibody therapies. Cancer Res 2007;67:2643-2648. [PubMed: 17363584]

153. De Roock W, Piessevaux H, De Schutter J, Janssens M, De Hertogh G, Personeni N, Biesmans B, Van Laethem JL, Peeters M, Humblet Y, Van Cutsem E, Tejpar S. KRAS wild-type state predicts survival and is associated to early radiological response in metastatic colorectal cancer treated with cetuximab. Ann. Oncol 2008;19:508-515. [PubMed: 17998284]

154. Di Fiore F, Blanchard F, Charbonnier F, Le Pessot F, Lamy A, Galais MP, Bastit L, Killian A, Sesboue R, Tuech JJ, Queuniet AM, Paillot B, Sabourin JC, Michot F, Michel P, Frebourg T. Clinical relevance of KRAS mutation detection in metastatic colorectal cancer treated by cetuximab plus chemotherapy. Br. J. Cancer 2007;96:1166-1169. [PubMed: 17375050]

155. Lievre A, Bachet JB, Le Corre D, Boige V, Landi B, Emile JF, Cote JF, Tomasic G, Penna C, Ducreux M, Rougier P, Penault-Llorca F, Laurent-Puig P. KRAS mutation status is predictive of response to cetuximab therapy in colorectal cancer. Cancer Res 2006;66:3992-3995. [PubMed: 16618717]

156. Khambata-Ford S, Garrett CR, Meropol NJ, Basik M, Harbison CT, Wu S, Wong TW, Huang X, Takimoto CH, Godwin AK, Tan BR, Krishnamurthi SS, Burris HA III, Poplin EA, Hidalgo M, Baselga J, Clark EA, Mauro DJ. Expression of epiregulin and amphiregulin and K-ras mutation status predict disease control in metastatic colorectal cancer patients treated with cetuximab. J. Clin. Oncol 2007;25:3230-3237. [PubMed: 17664471]

157. Amado RG, Wolf M, Peeters M, Van Cutsem E, Siena S, Freeman DJ, Juan T, Sikorski R, Suggs S, Radinsky R, Patterson SD, Chang DD. Wild-type KRAS is required for panitumumab efficacy in patients with metastatic colorectal cancer. J. Clin. Oncol 2008;26:1626-1634. [PubMed: 18316791]

158. Tejpar, S.; De Roock, W.; Beismans, B.; De Schutter, J.; Piessevaux, H.; Humblet, Y.; Peeters, M.; Celik, I.; Van Cutsem, E. Correlation of high amphiregulin and epiregulin expression in KRAS wild type colorectal primamries with response and survival benefit after treatment with cetuximaband irinocan for metastatic disease. Gastrointestinal Cancers Symposium ASCO; Orlando. 2008; Abstract 411

159. Sizemore N, Cox AD, Barnard JA, Oldham SM, Reynolds ER, Der CJ, Coffey RJ. Pharmacological inhibition of Ras-transformed epithelial cell growth is linked to down-regulation of epidermal growth factor-related peptides. Gastroenterology 1999;117:567-576. [PubMed: 10464132]

160. Lu Y, Li X, Liang K, Luwor R, Siddik ZH, Mills GB, Mendelsohn J, Fan Z. Epidermal growth factor receptor (EGFR) ubiquitination as a mechanism of acquired resistance escaping treatment by the anti-EGFR monoclonal antibody cetuximab. Cancer Res 2007;67:8240-8247. [PubMed: 17804738]

161. Li X, Lu Y, Liang K, Pan T, Mendelsohn J, Fan Z. Requirement of hypoxia-inducible factor-1alpha down-regulation in mediating the antitumor activity of the anti-epidermal growth factor receptor monoclonal antibody cetuximab. Mol. Cancer Ther 2008;7:1207-1217. [PubMed: 18483308]

162. Rothenberg ML, LaFleur B, Levy DE, Washington MK, Morgan-Meadows SL, Ramanathan RK, Berlin JD, Benson AB III, Coffey RJ. Randomized phase II trial of the clinical and biological effects of two dose levels of gefitinib in patients with recurrent colorectal adenocarcinoma. J. Clin. Oncol 2005;23:9265-9274. [PubMed: 16361624]

163. Kapitanovic S, Radosevic S, Kapitanovic M, Andelinovic S, Ferencic Z, Tavassoli M, Primorac D, Sonicki Z, Spaventi S, Pavelic K, Spaventi R. The expression of p185(HER-2/neu) correlates with the stage of disease and survival in colorectal cancer. Gastroenterology 1997;112:1103-1113. [PubMed: 9097992]

164. Saeki T, Salomon DS, Johnson GR, Gullick WJ, Mandai K, Yamagami K, Moriwaki S, Tanada M, Takashima S, Tahara E. Association of epidermal growth factor-related peptides and type I receptor 
tyrosine kinase receptors with prognosis of human colorectal carcinomas. Jpn. J. Clin. Oncol 1995;25:240-249. [PubMed: 8523820]

165. Mann M, Sheng H, Shao J, Williams CS, Pisacane PI, Sliwkowski MX, DuBois RN. Targeting cyclooxygenase 2 and HER-2/neu pathways inhibits colorectal carcinoma growth. Gastroenterology 2001;120:1713-1719. [PubMed: 11375952]

166. Ramanathan RK, Hwang JJ, Zamboni WC, Sinicrope FA, Safran H, Wong MK, Earle M, Brufsky A, Evans T, Troetschel M, Walko C, Day R, Chen HX, Finkelstein S. Low overexpression of HER-2/ neu in advanced colorectal cancer limits the usefulness of trastuzumab (Herceptin) and irinotecan as therapy. A phase II trial. Cancer Invest 2004;22:858-865. [PubMed: 15641483]

167. Kuwada SK, Scaife CL, Kuang J, Li X, Wong RF, Florell SR, Coffey RJ Jr. Gray PD. Effects of trastuzumab on epidermal growth factor receptor-dependent and -independent human colon cancer cells. Int. J. Cancer 2004;109:291-301. [PubMed: 14750183]

168. Kountourakis P, Pavlakis K, Psyrri A, Rontogianni D, Xiros N, Patsouris E, Pectasides D, Economopoulos T. Prognostic significance of HER3 and HER4 protein expression in colorectal adenocarcinomas. BMC Cancer 2006;6:46. [PubMed: 16507107]

169. Rokavec M, Justenhoven C, Schroth W, Istrate MA, Haas S, Fischer HP, Vollmert C, Illig T, Hamann U, Ko YD, Glavac D, Brauch H. A novel polymorphism in the promoter region of ERBB4 is associated with breast and colorectal cancer risk. Clin. Cancer Res 2007;13:7506-7514. [PubMed: 18094435]

170. Groenestege WM, Thebault S, van der Wijst J, van den Berg D, Janssen R, Tejpar S, van den Heuvel LP, van Cutsem E, Hoenderop JG, Knoers NV, Bindels RJ. Impaired basolateral sorting of proEGF causes isolated recessive renal hypomagnesemia. J. Clin. Invest 2007;117:2260-2267. [PubMed: 17671655]

171. Li C, Franklin JL, Graves-Deal R, Jerome WG, Cao Z, Coffey RJ. Myristoylated Naked2 escorts transforming growth factor alpha to the basolateral plasma membrane of polarized epithelial cells. Proc. Natl. Acad. Sci. U. S. A 2004;101:5571-5576. [PubMed: 15064403]

172. Li C, Hao M, Cao Z, Ding W, Graves-Deal R, Hu J, Piston DW, Coffey RJ. Naked2 acts as a cargo recognition and targeting protein to ensure proper delivery and fusion of TGF-alpha containing exocytic vesicles at the lower lateral membrane of polarized MDCK cells. Mol. Biol. Cell 2007;18:3081-3093. [PubMed: 17553928]

173. Cao Z, Li C, Higginbotham JN, Franklin JL, Tabb DL, Graves-Deal R, Hill S, Cheek K, Jerome WG, Lapierre LA, Goldenring JR, Ham AJ, Coffey RJ. Use of fluorescence-activated vesicle sorting for isolation of naked2-associated, basolaterally-targeted exocytic vesicles for proteomic analysis. Mol. Cell Proteomics 2008;7:1651-1667. [PubMed: 18504258]

174. Ding W, Li C, Hu T, Graves-Deal R, Fotia AB, Weissman AM, Coffey RJ. EGF receptorindependent action of TGF-alpha protects Naked2 from AO7-mediated ubiquitylation and proteasomal degradation. Proc. Natl. Acad. Sci. U. S. A 2008;105:13433-13438. [PubMed: 18757723]

175. Caldwell GM, Jones CE, Soon Y, Warrack R, Morton DG, Matthews GM. Reorganisation of Wntresponse pathways in colorectal tumorigenesis. Br. J. Cancer 2008;98:1437-1442. [PubMed: 18414471]

176. Ebner R, Derynck R. Epidermal growth factor and transforming growth factor-alpha: differential intracellular routing and processing of ligand-receptor complexes. Cell Reg 1991;2:599-612.

177. Hackel PO, Zwick E, Prenzel N, Ullrich A. Epidermal growth factor receptors: critical mediators of multiple receptor pathways. Curr. Opin. Cell Biol 1999;11:184-189. [PubMed: 10209149]

178. Yarden Y, Ullrich A. Growth factor receptor tyrosine kinases. Ann. Rev. Biochem 1988;57:443478. [PubMed: 3052279]

179. Chung E, Cook PW, Parkos CA, Park YK, Pittelkow MR, Coffey RJ. Amphiregulin causes functional downregulation of adherens junctions in psoriasis. J. Invest. Dermatol 2005;124:1134-1140. [PubMed: 15955087]

180. Chung E, Graves-Deal R, Franklin JL, Coffey RJ. Differential effects of amphiregulin and TGFalpha on the morphology of MDCK cells. Exp. Cell Res 2005;309:149-160. [PubMed: 15979068] 
181. Nam KT, Varro A, Coffey RJ, Goldenring JR. Potentiation of oxyntic atrophy-induced gastric metaplasia in amphiregulin-deficient mice. Gastroenterology 2007;132:1804-1819. [PubMed: 17484876]

182. Shao J, Sheng GG, Mifflin RC, Powell DW, Sheng H. Roles of myofibroblasts in prostaglandin E2stimulated intestinal epithelial proliferation and angiogenesis. Cancer Res 2006;66:846-855. [PubMed: 16424017]

183. Wiesen JF, Young P, Werb Z, Cunha GR. Signaling through the stromal epidermal growth factor receptor is necessary for mammary ductal development. Development (Cambridge, England) 1999;126:335-344.

184. van der Merwe JQ, Hollenberg MD, MacNaughton WK. EGF receptor transactivation and MAP kinase mediate proteinase-activated receptor-2-induced chloride secretion in intestinal epithelial cells. Am. J. Physiol 2008;294:G441-G451.

185. Darmoul D, Gratio V, Devaud H, Peiretti F, Laburthe M. Activation of proteinase-activated receptor 1 promotes human colon cancer cell proliferation through epidermal growth factor receptor transactivation. Mol. Cancer Res 2004;2:514-522. [PubMed: 15383630]

186. Koon HW, Zhao D, Na X, Moyer MP, Pothoulakis C. Metalloproteinases and transforming growth factor-alpha mediate substance P-induced mitogen-activated protein kinase activation and proliferation in human colonocytes. J. Biol. Chem 2004;279:45519-45527. [PubMed: 15319441]

187. Keates S, Han X, Kelly CP, Keates AC. Macrophage-inflammatory protein-3alpha mediates epidermal growth factor receptor transactivation and ERK1/2 MAPK signaling in Caco-2 colonic epithelial cells via metalloproteinase-dependent release of amphiregulin. J. Immunol 2007;178:8013-8021. [PubMed: 17548638]

188. Itoh Y, Joh T, Tanida S, Sasaki M, Kataoka H, Itoh K, Oshima T, Ogasawara N, Togawa S, Wada T, Kubota H, Mori Y, Ohara H, Nomura T, Higashiyama S, Itoh M. IL-8 promotes cell proliferation and migration through metalloproteinase-cleavage proHB-EGF in human colon carcinoma cells. Cytokine 2005;29:275-282. [PubMed: 15749028]

189. Tanida S, Joh T, Itoh K, Kataoka H, Sasaki M, Ohara H, Nakazawa T, Nomura T, Kinugasa Y, Ohmoto H, Ishiguro H, Yoshino K, Higashiyama S, Itoh M. The mechanism of cleavage of EGFR ligands induced by inflammatory cytokines in gastric cancer cells. Gastroenterology 2004;127:559_ 569. [PubMed: 15300588]

190. Ancha HR, Kurella RR, Stewart CA, Damera G, Ceresa BP, Harty RF. Histamine stimulation of MMP-1(collagenase-1) secretion and gene expression in gastric epithelial cells: role of EGFR transactivation and the MAP kinase pathway. Int. J. Biochem. Cell Biol 2007;39:2143-2152. [PubMed: 17656145]

191. Shida D, Kitayama J, Yamaguchi H, Yamashita H, Mori K, Watanabe T, Nagawa H. Lysophosphatidic acid transactivates both c-Met and epidermal growth factor receptor, and induces cyclooxygenase-2 expression in human colon cancer LoVo cells. World J. Gastroenterol 2005;11:5638-5643. [PubMed: 16237757]

192. Grant K, Knowles J, Dawas K, Burnstock G, Taylor I, Loizidou M. Mechanisms of endothelin 1stimulated proliferation in colorectal cancer cell lines. Br. J. Surg 2007;94:106-112. [PubMed: 17078114]

193. Chiu T, Santiskulvong C, Rozengurt E. EGF receptor transactivation mediates ANG II-stimulated mitogenesis in intestinal epithelial cells through the PI3-kinase/Akt/mTOR/p70S6K1 signaling pathway. Am. J. Physiol 2005;288:G182-G194.

194. Pai R, Soreghan B, Szabo IL, Pavelka M, Baatar D, Tarnawski AS. Prostaglandin E2 transactivates EGF receptor: a novel mechanism for promoting colon cancer growth and gastrointestinal hypertrophy. Nature Med 2002;8:289-293. [PubMed: 11875501]

195. Tessner TG, Muhale F, Riehl TE, Anant S, Stenson WF. Prostaglandin E2 reduces radiation-induced epithelial apoptosis through a mechanism involving AKT activation and bax translocation. J. Clin. Invest 2004;114:1676-1685. [PubMed: 15578100]

196. Buchanan FG, Wang D, Bargiacchi F, DuBois RN. Prostaglandin E2 regulates cell migration via the intracellular activation of the epidermal growth factor receptor. J. Biol. Chem 2003;278:3545135457. [PubMed: 12824187] 
197. Barber TD, Vogelstein B, Kinzler KW, Velculescu VE. Somatic mutations of EGFR in colorectal cancers and glioblastomas. N. Engl. J. Med 2004;351:2883. [PubMed: 15625347] 


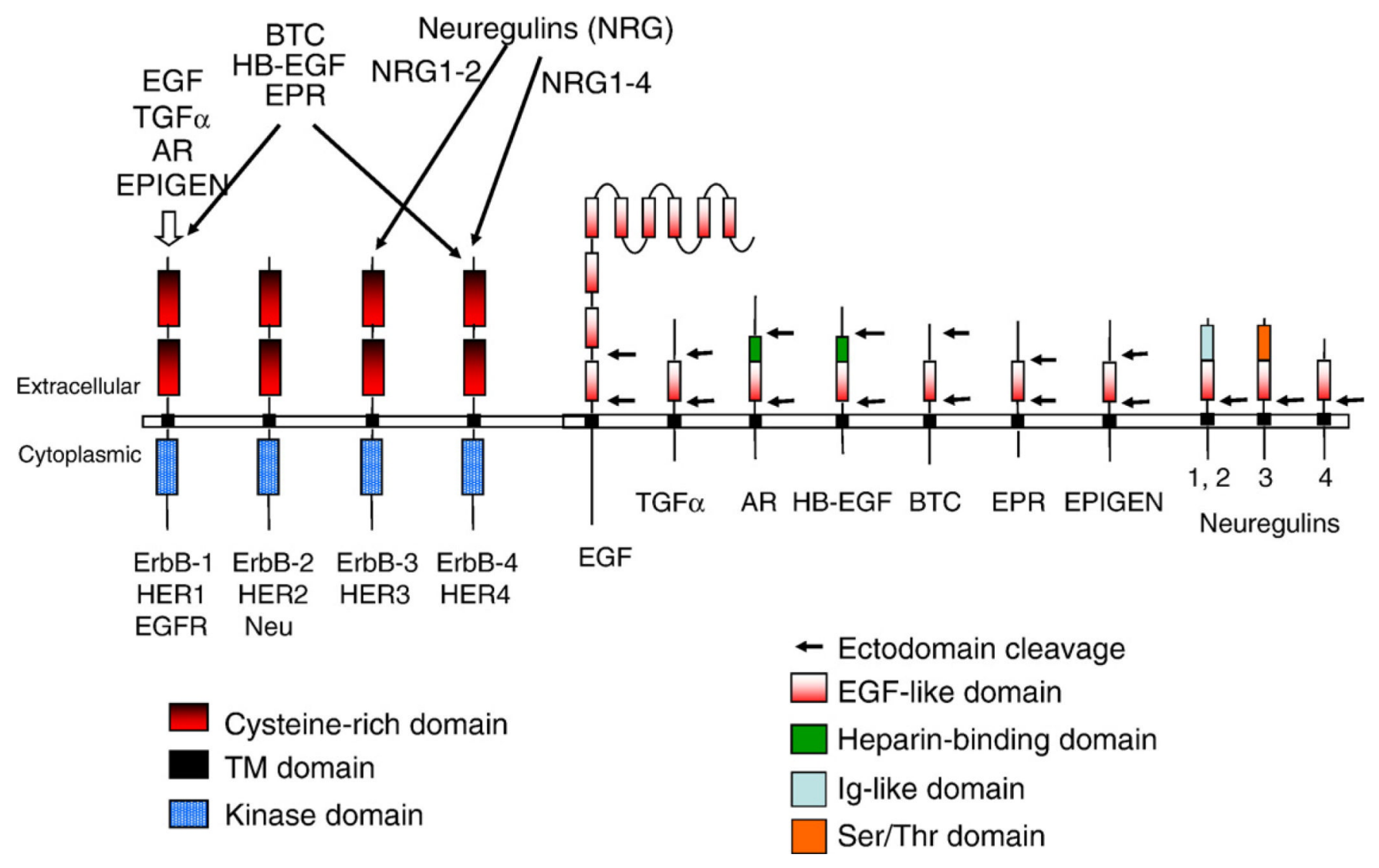

Fig. 1.

Depiction of ERBBs and their cognate ligands. See text for details. AR, amphiregulin; BTC, betacellulin; EPR, epiregulin. 
A
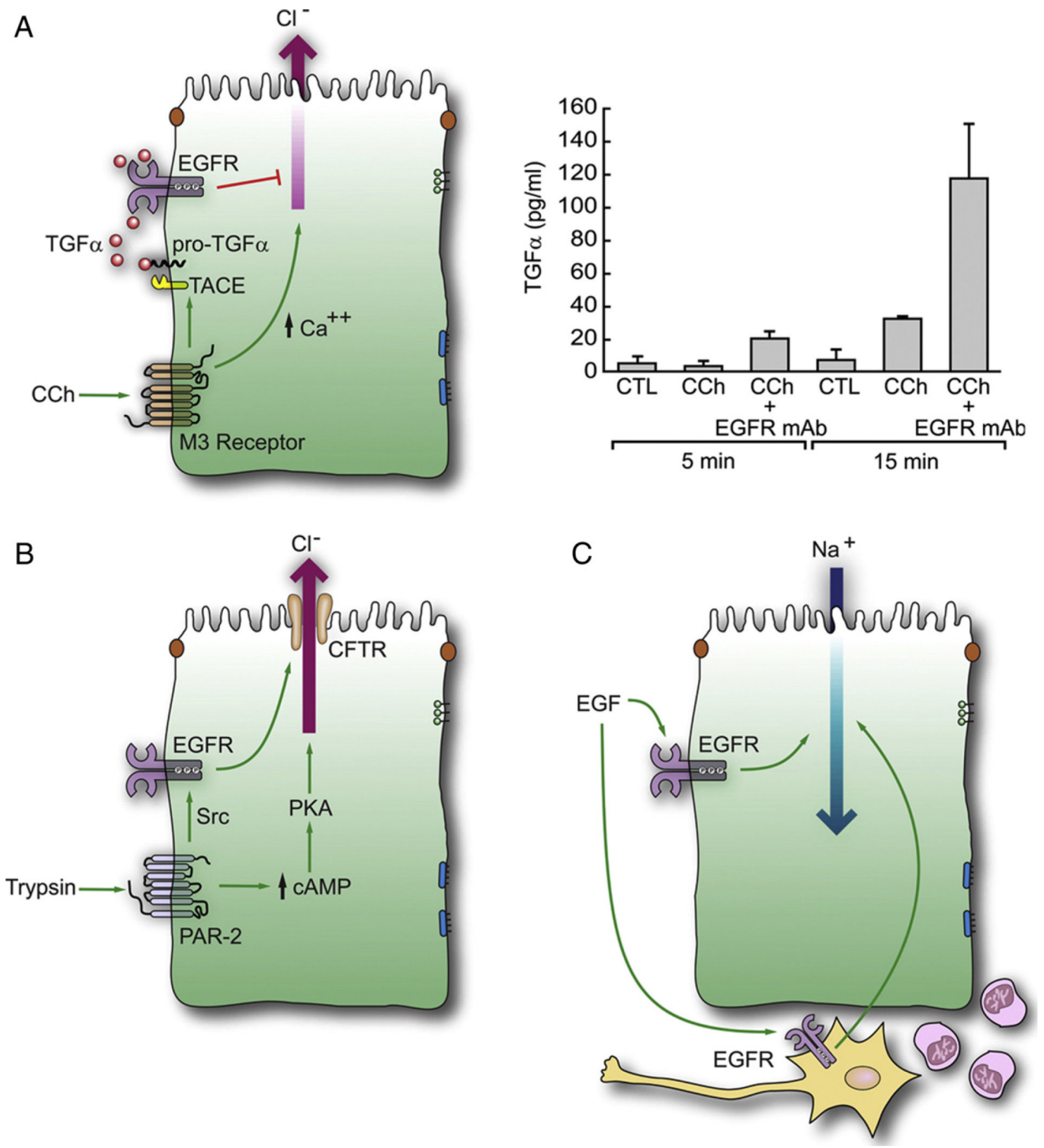

Fig. 2.

Simplified schema depicting effect of EGFR signaling on overall chloride secretion. Except for CFTR, it is not intended to represent specific chloride or sodium transporters. Panels A and B summarize studies performed in polarized T84 cells. (A) Left panel, carbachol (CCh) binds and activates basolateral GPCR M3 muscarinic receptors that stimulate rapid, yet transient, calcium-dependent apical chloride secretion. CCh activation of $\mathrm{M} 3$ receptors also triggers ectodomain cleavage of proTGF $\alpha$ by TACE. The soluble ligand is avidly captured by basolateral EGFRs; this transmits an incompletely understood signal that dampens chloride secretion. Right panel, upon CCh stimulation, there is TACE-mediated rapid ectodomain cleavage of TGF $\alpha$ and the soluble ligand is avidly captured by basolateral EGFRs (adapted 
from Fig. 7 in reference [29]). (B) In contrast to calcium-mediated chloride secretion, increased intracellular cAMP (achieved e.g. by PAR-2, VIP, dibutryl cAMP, forskolin) stimulates slower onset, more sustained chloride secretion by a PKA-mediated direct effect on the CFTR chloride channel. Depicted here is activation of basolateral PAR-2 that results in Src-dependent transactivation of the EGFR. In this instance, there appears to be ligand-independent EGFR activation that contributes to chloride secretion. (C) In normal mouse colon, addition of EGF inhibits cAMP-dependent ion transport; however, in the setting of inflammation, EGF stimulates sodium reabsorption. In the inflamed mouse colon, this effect is blunted by tetrodotoxin, indicating that the effect is mediated, at least in part, through neurons.(P) indicates activated, tyrosine phosphorylated EGFR. 


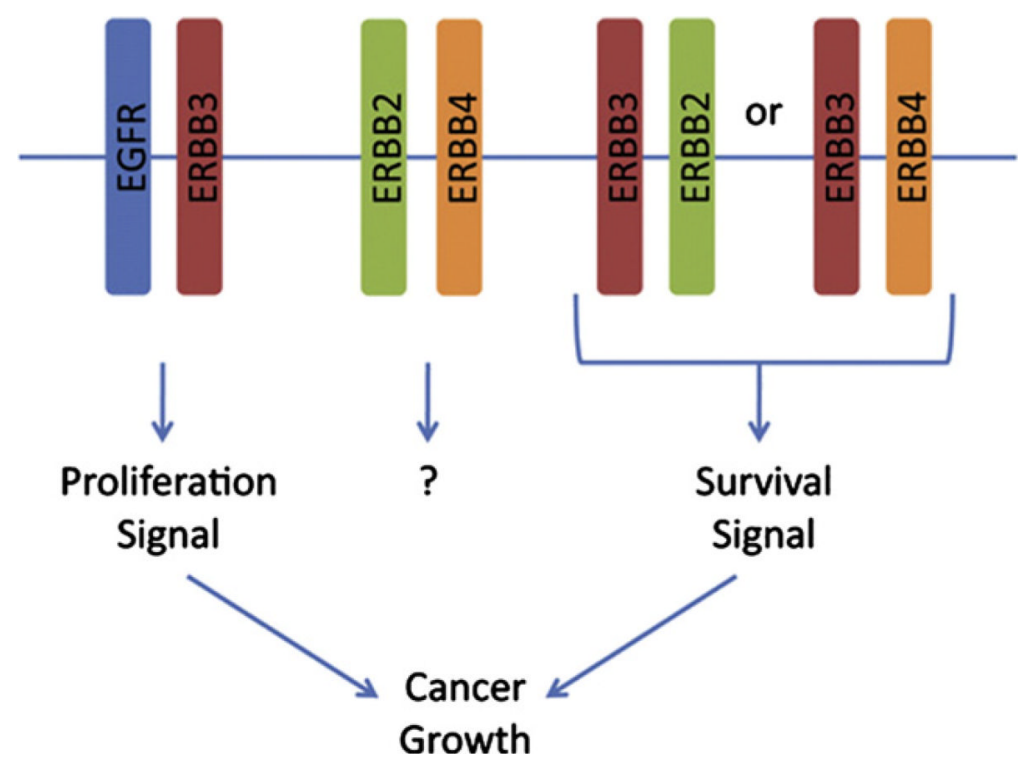

Fig. 3.

Receptor combinations contributing to CRC growth. Results from inhibiting EGFR or conditional deletion of ErbB3 is consistent with a model whereby EGFR-containing dimers contribute to proliferation, while ErbB3 dimers largely contribute to survival. CRC growth requires both signals. When EGFR is blocked, tumors have reduced proliferation. However, tumors that lack EGFR have normal growth rates, presumably using other ErbB signals. When ErbB3 is lost, both a proliferation and survival signal are lost, resulting in a dramatic reduction in tumorigenesis. 
A

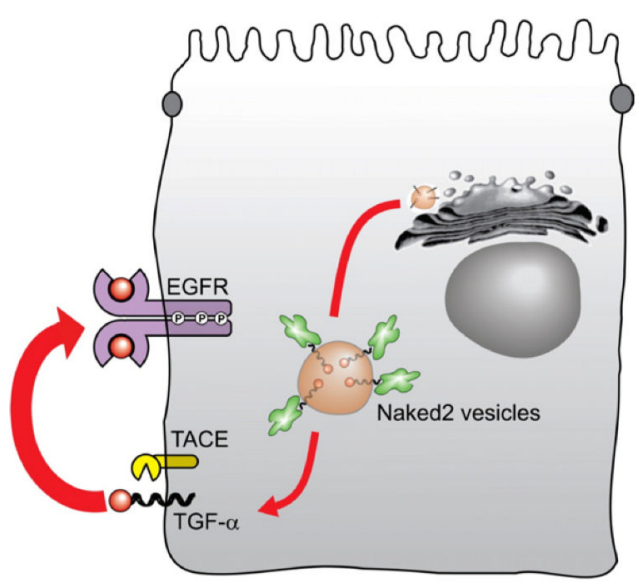

$\mathrm{B}$
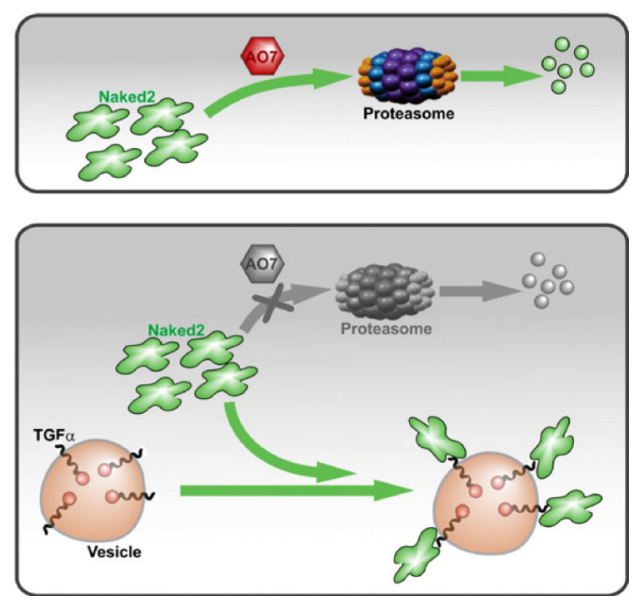

Fig. 4.

Model for TGF $\alpha$-induced Naked2 stabilization. (A) Naked2 acts as a CaRT to escort TGF $\alpha$ containing vesicles to the basolateral corner of polarized epithelial cells where they dock and fuse in Naked2 myristoylation-dependent manner. (B) In the absence of TGF $\alpha$, Naked2 is ubiquitylated by $\mathrm{AO} 7$ and undergoes rapid proteasomal degradation. When TGF $\alpha$ binds Naked2, there is decreased binding of AO7 to Naked2 and Naked2 is protected from degradation. This action of TGF $\alpha$ is EGFR-independent. Figure is adapted from reference [172]. 


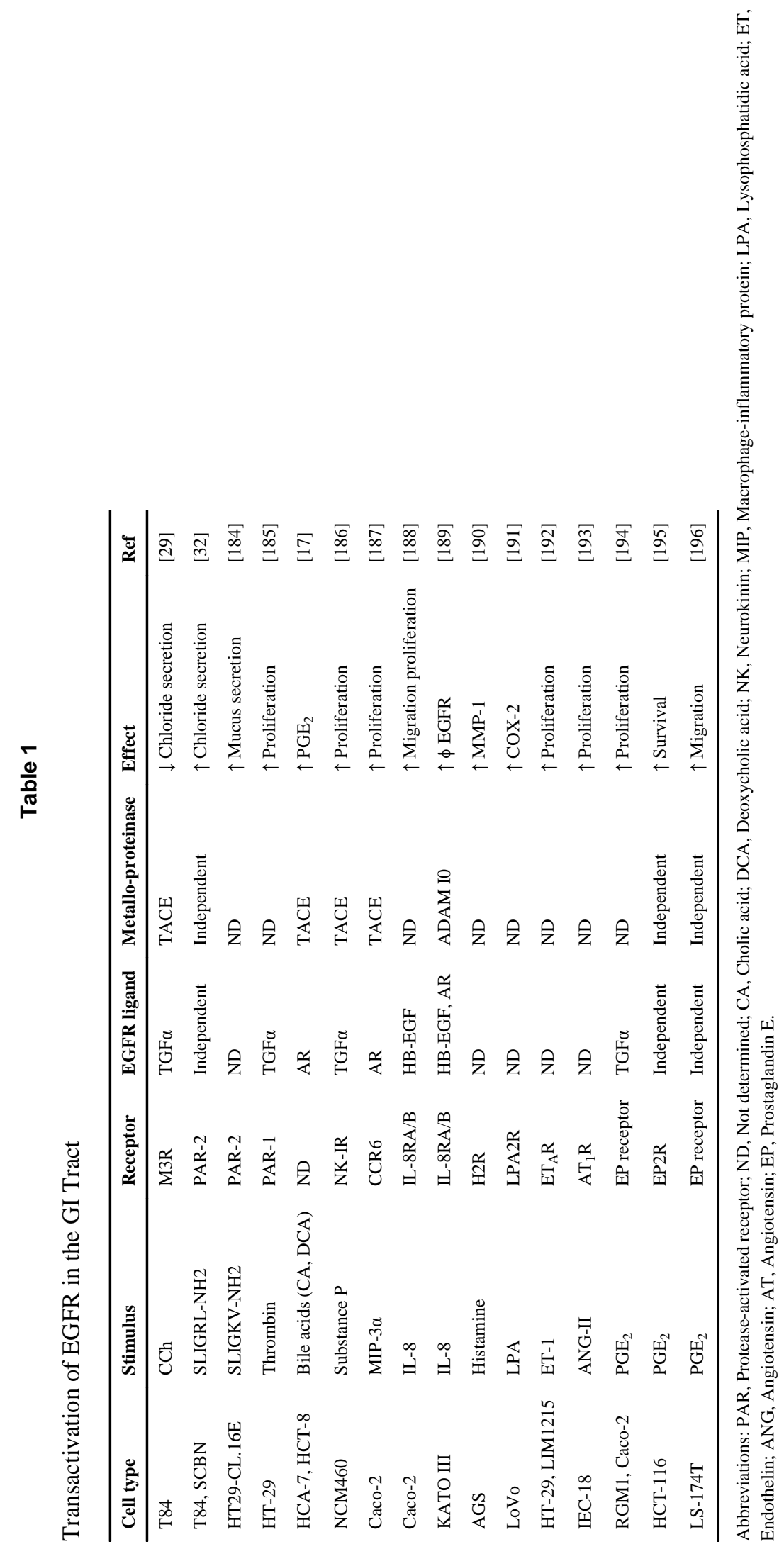

Exp Cell Res. Author manuscript; available in PMC 2010 September 20. 